\title{
Transactions
}

Cite this: Dalton Trans., 2011, 40, 10174

wWW.rsc.org/dalton

PAPER

\section{Synthesis and characterization of platinum(II) di-ynes and poly-ynes incorporating ethylenedioxythiophene (EDOT) spacers in the backbone $\uparrow$}

\author{
Muhammad S. Khan, ${ }^{* a}$ Mohammed K. Al-Suti, ${ }^{a}$ Hakkikulla H. Shah, ${ }^{a}$ Said Al-Humaimi, ${ }^{a}$ \\ Fathiya R. Al-Battashi, ${ }^{a}$ Jens K. Bjernemose, ${ }^{b}$ Louise Male, ${ }^{b}$ Paul R. Raithby, ${ }^{* b}$ Ning Zhang, ${ }^{c}$ Anna Köhler ${ }^{c}$ \\ and John E. Warren ${ }^{d}$
}

Received 30th May 2011, Accepted 22nd July 2011

DOI: 10.1039/c1dt11010a

\begin{abstract}
A series of trimethylsilyl-protected di-alkynes incorporating 3,4-ethylenedioxythiophene (EDOT) linker groups $\mathrm{Me}_{3} \mathrm{Si}-\mathrm{C} \equiv \mathrm{C}-\mathrm{R}-\mathrm{C} \equiv \mathrm{C}-\mathrm{SiMe}_{3}(\mathrm{R}=$ ethylenedioxythiophene-3,4-diyl 1a, 2,2'-bis-3,4ethylenedioxythiophene-5,5'-diyl 2a, 2,2',5',2'-ter-3,4-ethylenedioxythiophene-5,5'-diyl 3a) and the corresponding terminal di-alkynes, $\mathrm{H}-\mathrm{C} \equiv \mathrm{C}-\mathrm{R}-\mathrm{C} \equiv \mathrm{C}-\mathrm{H} \mathbf{1 b}-\mathbf{2} \mathbf{b}$ has been synthesized and characterized and the single crystal $\mathrm{X}$-ray structure of $\mathbf{1 a}$ has been determined. CuI-catalyzed dehydrohalogenation reaction between trans- $\left[(\mathrm{Ph})\left(\mathrm{Et}_{3} \mathrm{P}\right)_{2} \mathrm{PtCl}\right]$ and the terminal di-alkynes $\mathbf{1 b}-\mathbf{2} \mathbf{b}$ in ${ }^{i} \mathrm{Pr}_{2} \mathrm{NH} / \mathrm{CH}_{2} \mathrm{Cl}_{2}(2: 1$ mole ratio) gives the $\mathrm{Pt}(\mathrm{II})$ di-ynes trans- $\left[\left(\mathrm{Et}_{3} \mathrm{P}\right)_{2}(\mathrm{Ph}) \mathrm{Pt}-\mathrm{C} \equiv \mathrm{C}-\mathrm{R}-\mathrm{C} \equiv \mathrm{C}-\mathrm{Pt}(\mathrm{Ph})\left(\mathrm{Et}_{3} \mathrm{P}\right)_{2}\right] \mathbf{1} \mathbf{M}-\mathbf{2 M}$ while the dehydrohalogenation polycondensation reaction between trans- $\left[\left({ }^{n} \mathrm{Bu}_{3} \mathrm{P}\right)_{2} \mathrm{PtCl}_{2}\right]$ and $\mathbf{1 b}-\mathbf{2} \mathbf{b}(1: 1$ mole ratio) under similar reaction conditions affords the $\mathrm{Pt}(\mathrm{II})$ poly-ynes trans- $\left[\mathrm{Pt}\left(\mathrm{P}^{n} \mathrm{Bu}_{3}\right)_{2}-\mathrm{C} \equiv \mathrm{C}-\mathrm{R}-\mathrm{C} \equiv \mathrm{C}-\right]_{n}$ 1P-2P. The di-ynes and poly-ynes have been characterized spectroscopically and, for $\mathbf{1 M}$ and $\mathbf{2 M}$, by single-crystal X-ray which confirms the "rigid rod" di-yne backbone. The materials possess excellent thermal stability, are soluble in common organic solvents and readily cast into thin films. Optical absorption spectroscopic measurements reveal that the EDOT spacers create stronger donor-acceptor interactions between the platinum(II) centres and conjugated ligands along the rigid backbone of the organometallic polymers compared to the related non-fused and fused oligothiophene spacers.
\end{abstract}

\section{Introduction}

Conjugated polymers are used as light emitting diodes (LEDs), ${ }^{1}$ lasers, ${ }^{2}$ photocells, ${ }^{3}$ sensors, ${ }^{4}$ piezo- and pyro-electric materials, ${ }^{5}$ and are being investigated for use as optical data storage devices, ${ }^{6}$ as optical switches and signal processing devices ${ }^{7}$ as well as having nonlinear optical (NLO) applications. ${ }^{8}$ Within the domain of conjugated polymers two classes of material have sparked special interest. The first class of materials is the polythiophenes because of their applications as organic semiconductors for transistor applications and photovoltaic cells. ${ }^{9}$ The second class of materials comprises the "rigid-rod" platinum poly-yne polymers of general formula trans $-\left[\left({ }^{n} \mathrm{Bu}_{3} \mathrm{P}\right)_{2} \mathrm{Pt}-\mathrm{C} \equiv \mathrm{C}-\mathrm{R}-\mathrm{C} \equiv \mathrm{C}-\right]_{\infty}$, where $\mathrm{R}$ is a conjugated spacer group. ${ }^{10}$ Metallopolymers derived from platinum(II) alkynyl structural units have been studied widely

aDepartment of Chemistry, Sultan Qaboos University, P.O. Box 36, Al Khod, 123, Sultanate of Oman.E-mail: msk@squ.edu.om

${ }^{b}$ Department of Chemistry, University of Bath, Claverton Down, Bath, UK, BA2 7AY.E-mail:p.r.raithby@bath.ac.uk; Fax:+44 1225 386231; Tel: +44 1225383183

'Department of Physics, University of Bayreuth, Bayreuth, 95440, Germany ${ }^{d}$ The STFC Daresbury Laboratory, Daresbury, Warrington, UK, WA4 4AD $\dagger$ CCDC reference numbers 828207 and 828209 . For crystallographic data in CIF or other electronic format see DOI: $10.1039 / \mathrm{cldt1} 1010 \mathrm{a}$ as $\pi$-conjugated materials featuring high quantum efficiency for inter-system crossing to produce the triplet excited state following direct excitation, providing considerable insight concerning the electronic structure, delocalization, and dynamics of the triplet exciton. $^{11}$

We have combined the polythiophenes with the platinum(II) poly-ynes by incorporating a broad range of oligothiophene spacers into platinum(II) poly-ynes and investigated the electronic structure of the singlet (S1) and triplet (T1) excited states in fused and non-fused oligothiophenes. ${ }^{12}$ The energies of the optical transitions for the $\mathrm{S} 1$ and $\mathrm{T} 1$ states shift to higher energies when going from the non-fused to the fused systems. The shift in electronic energies to higher values in fused system compared to non-fused system with the same number of thiophene rings is attributed to the level of conjugation within the oligothiophene spacers. The greater the number of conjugated double bonds, the lower is the energy gap. Apart from the non-fused and fused thiophene ring systems, 3,4-ethylenedioxythiophene (EDOT) also occupies a prominent position as the functional component for conjugated polymers due, among other things, to the strong electron donor effect of the ethylenedioxy group, the self-rigidification of the structure by non-covalent intermolecular interactions as well as quinoidization of the conjugated system. ${ }^{13}$ The past decade has witnessed some spectacular development in EDOT-based organic polymers and 
copolymers ${ }^{14}$ but the organometallic chemistry based on the EDOT system remains relatively unexplored. To the best of our knowledge, there has been no report of EDOT-containing metal alkynyl complexes and polymers except two recent reports on the use of EDOT-benzothiadiazole hybrid spacer in platinum(II) polyynes. ${ }^{15}$

This background prompted us to undertake the synthesis of platinum(II) poly-ynes incorporating EDOT spacers in the backbone, the motivation for their synthesis is to extend the range of organometallic polymers and establish in what way the incorporation of EDOT spacers affects the physico-chemical properties of the new materials. Recently, attention has also been directed toward $\pi$-conjugated dimers and oligomers, taken not only as model compounds for the high molecular weight polymers, but also as efficient molecular wires in electronic device applications. ${ }^{16}$ They are more crystalline than the corresponding polymers, allowing for a detailed structural analysis and, thus, an assessment of the structure-electronic property relationship. ${ }^{17}$ There is also considerable interest in the solid-state structures of the polymeric materials because of evidence for inter-chain interactions that influence their electronic properties. In this context an analysis of intermolecular interactions in the crystal structures of the dialkynyl ligands and of the model di-yne complexes may lead to a better understanding of the interactions in the poly-ynes. ${ }^{18}$ The structural analysis of a ligand precursor 1a and of two model dinuclear platinum(II) di-yne complexes, $\mathbf{1 M}$ and $\mathbf{2 M}$, are reported in this paper. Spectroscopic, thermal and optoelectronic properties of the new platinum(II) di-ynes and poly-ynes, 1M-2M and 1P-2P are also presented and compared with those of related organometallic complexes and polymers.

\section{Results and discussion}

\section{Synthesis}

The key starting materials for the dialkynyl ligand precursors, 2,5-diiodo-3,4-ethylenedioxythiophene, 5,5'-diiodo-2,2'-bis-3, 4-ethylenedioxythiophene and 5,5"-diiodo-2,2',5',2"-ter-3,4ethylenedioxythiophene were prepared in high yields by adaptation of a literature procedure involving iodination of EDOT/ bis-EDOT/tris-EDOT with iodine monochloride-pyridine complex. ${ }^{15}$ The bis-ethynyl ligands were synthesized by a sequence of cross-coupling and proto-desilylation reactions. The protected dialkynyl ligand precursors, 2,5-bis(trimethylsilylethynyl)-3,4ethylenedioxythiophene $\mathbf{1 a}, \quad 5,5^{\prime}$-bis(trimethylsilylethynyl)2,2'-bis-3,4-ethylenedioxythiophene $\mathbf{2 a}$ and 5,5"-bis(trimethylsilylethynyl)-2,2', $5^{\prime}, 2^{\prime}$-ter-3,4-ethylenedioxythiophene $\mathbf{3 a}$ were prepared by palladium(II)/copper(I)-catalyzed cross-coupling reaction of trimethylsilylethyne with the respective diiodo-EDOT, in ${ }^{i} \mathrm{Pr}_{2} \mathrm{NH}-\mathrm{THF}$ as illustrated in Scheme $1 .{ }^{19}$ The protected dialkynes are indefinitely stable towards light and air at ambient temperature and were fully characterised by IR, NMR $\left({ }^{1} \mathrm{H}\right.$ and ${ }^{13} \mathrm{C}$ ) spectroscopy, EI mass spectrometry, as well as by satisfactory elemental analyses. Conversion of the protected dialkynes 1a-2a into the diterminal alkynes, 2,5-bis(ethynyl)3,4-ethylenedioxythiophene $\mathbf{1 b}$, and 5,5'-bis(ethynyl)-2,2'-bis-3,4ethylenedioxythiophene $\mathbf{2 b}$, was accomplished by cleavage of the trimethylsilyl groups with dilute aqueous $\mathrm{KOH}$ in $\mathrm{MeOH}-\mathrm{THF}$ (Scheme 1). The products were purified by silica gel column chromatography and isolated as orange to red solids in $78-85 \%$ yields. The diterminal alkynes $\mathbf{1} \mathbf{b}$ and $\mathbf{2 b}$ are somewhat unstable; storage over a long period of time at ambient temperature and under aerobic conditions leads to the formation of dark insoluble material that was presumed to be polymerization products. Hence, $\mathbf{1 b}$ and $\mathbf{2 b}$ were prepared freshly before reaction with the platinum(II) phosphine complexes. The diterminal alkyne $\mathbf{3 b}$ rapidly decomposed as formed during the cleavage reaction and therefore could not be isolated for reaction with the platinum(II) phosphine complexes.

The dehydrohalogenation reactions between trans$\left[(\mathrm{Ph})\left(\mathrm{Et}_{3} \mathrm{P}\right)_{2} \mathrm{PtCl}\right]$ and the diterminal alkynes $\mathbf{1 b}-\mathbf{2 b}$ in a $2: 1$ stoichiometry, in ${ }^{\mathrm{i}} \mathrm{Pr}_{2} \mathrm{NH}-\mathrm{CH}_{2} \mathrm{Cl}_{2}$, in the presence of $\mathrm{CuI}$ at room temperature gave the dinuclear platinum(II) di-ynes $\mathbf{1 M}-\mathbf{2} \mathbf{M}$ while

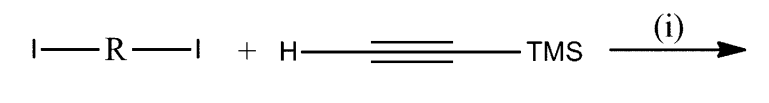

(i) ${ }^{i} \mathrm{Pr}_{2} \mathrm{NH} / \mathrm{THF}, \mathrm{Ph}_{3} \mathrm{P}, \mathrm{Pd}(\mathrm{OAc})_{2}, \mathrm{CuI}$

(ii) $\mathrm{OH}^{-}, \mathrm{MeOH} / \mathrm{THF}$

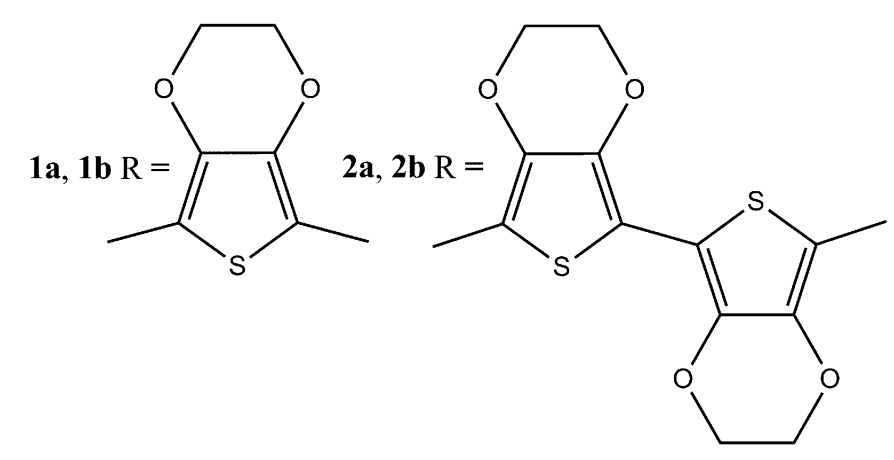

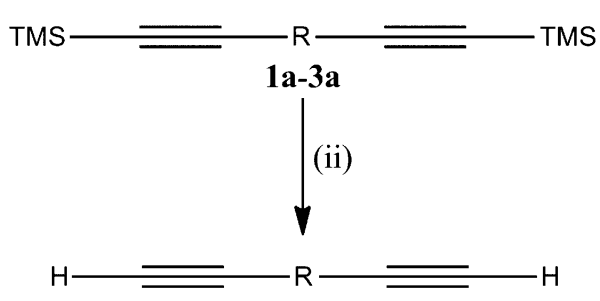

1b-3b

Scheme 1 


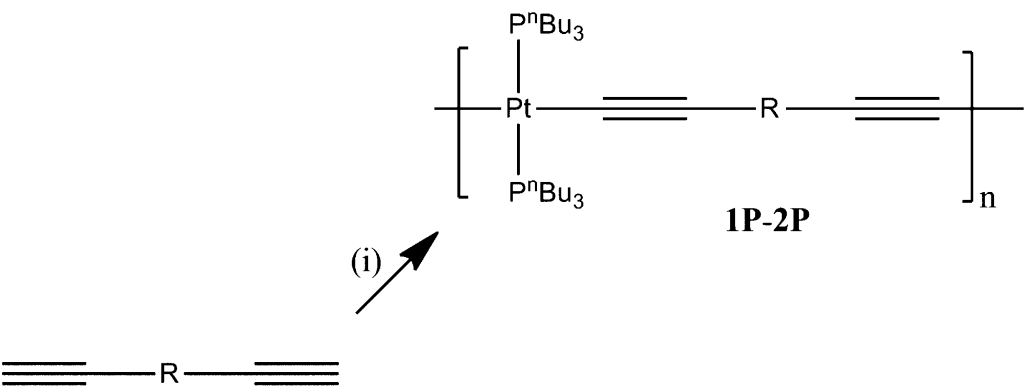

(ii)

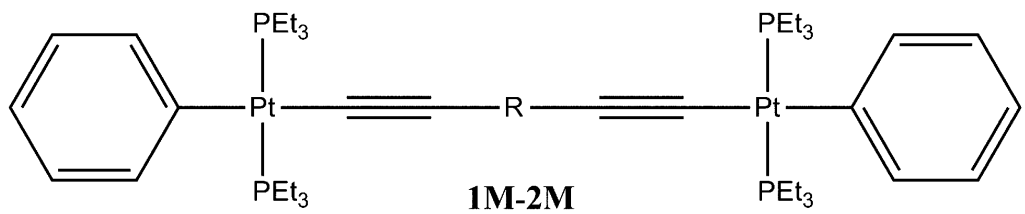

(i) Trans- $\left[\mathrm{PtCl}_{2}\left(\mathrm{P}^{\mathrm{n}} \mathrm{Bu}_{3}\right)_{2}\right](1$ equiv. $), \mathrm{CuI},{ }^{i} \mathrm{Pr}_{2} \mathrm{NH} / \mathrm{CH}_{2} \mathrm{Cl}_{2}$

(ii) Trans-[PtPhCl$\left.\left(\mathrm{PEt}_{3}\right)_{2}\right]$, , (2 equivs.)CuI, ${ }^{i} \mathrm{Pr}_{2} \mathrm{NH} / \mathrm{CH}_{2} \mathrm{Cl}_{2}$

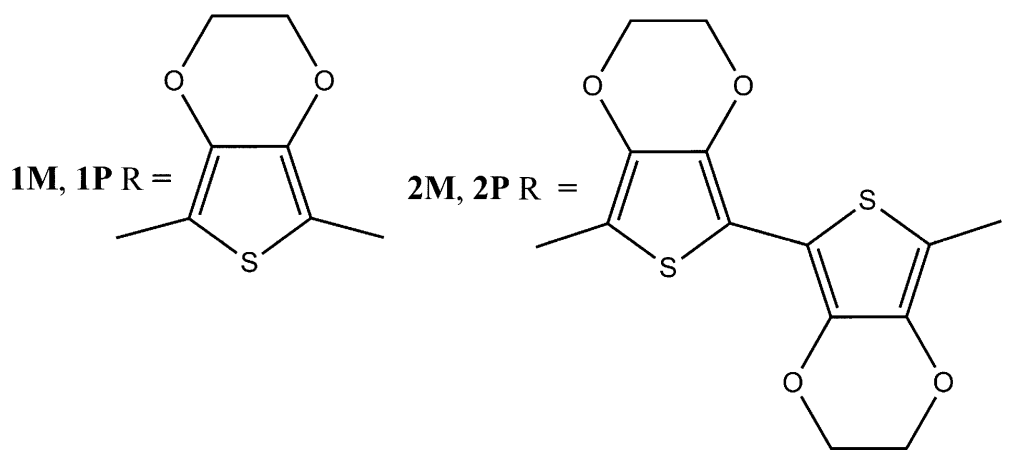

Scheme 2

the polycondensation reactions between trans- $\left[\left(\mathrm{P}^{n} \mathrm{Bu}_{3}\right)_{2} \mathrm{PtCl}_{2}\right]$ and $\mathbf{1 b}-\mathbf{2 b}$, in a $1: 1$ ratio, under similar reaction conditions, readily afforded the platinum(II) poly-ynes $\mathbf{1 P}$ and $\mathbf{2 P}$ (Scheme 2). The poly-ynes were obtained in yields of $85-90 \%$, pointing to a very high conversion.

Purification of the platinum(II) di-ynes was accomplished by column chromatography or preparative TLC on silica while the poly-ynes were purified by chromatography on an alumina column.

\section{Spectroscopic characterization}

Preliminary, systematic characterization of the organic ligand precursors as well as the platinum(II) di-ynes and poly-ynes was achieved by spectroscopic methods. The IR spectra of the platinum(II) di-ynes and poly-ynes show a single, sharp $v_{\mathrm{C} \equiv \mathrm{C}}$ absorption at around $2085 \mathrm{~cm}^{-1}$ consistent with a trans-configuration of the ethynylenic units around the platinum(II) centre, and the observed value is similar to that found in a range of related materials. ${ }^{20}$ The $v_{\mathrm{C}} \equiv_{\mathrm{C}}$ values for the terminal di-ynes $\mathbf{1 b}-\mathbf{2 b}(2107$ $\mathrm{cm}^{-1}$ ) are much lower than those of the trimethylsilyl-protected dialkynes 1a-2a $\left(2140-2150 \mathrm{~cm}^{-1}\right)$. The fact that terminal ethynes $(\mathrm{HC} \equiv \mathrm{C}-\mathrm{R})$ have lower $v_{\mathrm{C} \equiv \mathrm{C}}$ frequencies than their protected counterparts $\mathrm{RC} \equiv \mathrm{C}-\mathrm{R}$ (by about $40 \mathrm{~cm}^{-1}$ in this case) is well established. ${ }^{21}$ Furthermore, the platinum(II) di-ynes and polyynes display lower $v_{\mathrm{C} \equiv \mathrm{C}}$ values than those in the corresponding protected or terminal dialkynes. This may be attributed to either metal-yne $\pi$-backbonding or the $\mathrm{M}^{\delta+}-\mathrm{C}^{\delta-}$ polarity. ${ }^{22} \mathrm{NMR}$ analyses indicate a rigid structure for the platinum(II) di-ynes and polyynes. In all cases, ${ }^{1} \mathrm{H}$ NMR resonances arising from the protons of the aromatic ring systems were clearly observed. In addition, two distinct ${ }^{13} \mathrm{C}$ NMR peaks for the individual ethynylenic carbons in the di-ynes and poly-ynes were observed, in accord with their formulations, and they are shifted downfield with respect to the signals in the diterminal alkynes. The resonances due to the ethyl and butyl groups were clearly identified. The single resonance in the ${ }^{31} \mathrm{P}$ NMR spectra of the platinum(II) di-ynes and poly-ynes confirms the trans arrangement of the phosphine ligands. The ${ }^{1} J_{\mathrm{Pt}-\mathrm{P}}$ values range from 2628 to $2645 \mathrm{~Hz}$ for the di-ynes and 2363 $2377 \mathrm{~Hz}$ for the poly-ynes; the spectral features are quite similar to other platinum(II) di-ynes and poly-ynes reported previously ${ }^{12,20}$ and confirm the all-trans configuration of the compounds. 
The mass spectrometric results confirm the molecular assignments for the organic precursors and the platinum(II) di-ynes. Gel permeation chromatography (GPC), using a polystyrene (PS) standard shows that the number-average molecular weights $\left(\mathrm{M}_{n}\right)$ of the poly-ynes are in the range of 40,000-52,000 $\mathrm{gmol}^{-1}$, corresponding to degrees of polymerization of between 66 and 44 repeat units. The value of polydispersity index (PDI) varies between 1.4 and 1.7. The narrow polydispersity (PDI $<2$ ) in the molecular weights is consistent with the extended linear structure. GPC data indicate that the number of repeat unit per chain for the EDOT-containing poly-yne is higher than that for the bis(EDOT)-based poly-yne. The reduction in chain length with increasing size of the spacer group may reflect a reduction in solubility of the larger species. The molecular weight values should be viewed with caution in view of the difficulties associated with utilizing GPC for rigid-rod type polymers. GPC does not give absolute values of molecular weights but provides a measure of hydrodynamic volume. Rod-like polymers in solution possess very different hydrodynamic properties to flexible polymers. Therefore, calibration of the GPC with PS standards could inflate the values of the molecular weights of the poly-ynes to some extent. However, the lack of discernable resonances that could be attributed to end groups in the NMR spectra provides support for the view that a high degree of polymerization has been achieved in these organometallic polycondensation reactions.

\section{Crystal structure analysis}

Single crystals of compounds $\mathbf{1 a}, \mathbf{1 M}$ and $\mathbf{2 M}$ were obtained, and the crystal and molecular structures of these materials were determined in order to confirm the spectroscopic assignments, and investigate the intermolecular interactions in the solid state, with a view to correlating the structure/property relationships in these systems.

The molecular structure of 2,5-bis(trimethylsilylethynyl)-3,4ehyldioxythiophene 1a is shown in Fig. 1 along with selected bond parameters. The molecules show the expected linear geometry (average $\mathrm{Si}-\mathrm{C} \equiv \mathrm{C}, 171.8(3)^{\circ}$, and average $\mathrm{C} \equiv \mathrm{C}-\mathrm{C}, 177.3(4)^{\circ}$ along the two acetylene groups on either side of the ethylenedioxythiophene group). The two $\mathrm{C} \equiv \mathrm{C}$ bonds have an average length of 1.209(4) $\AA$, consistent with values found in a range of bistrimethylsilylethynyl derivatives. ${ }^{23}$ For the trimethylsilyl groups the

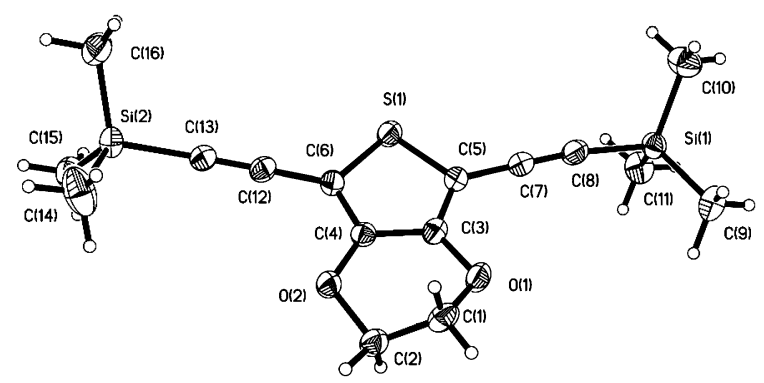

Fig. 1 The molecular structure of 1a with $50 \%$ thermal ellipsoids. Selected bond lengths $(\AA)$ and angles $\left(^{\circ}\right)$ : C(1)-O(1), 1.450(4); C(1)-C(2), 1.494(5); $\mathrm{C}(2)-\mathrm{O}(2), 1.447(4) ; \mathrm{C}(3)-\mathrm{O}(1), 1.363(4) ; \mathrm{C}(4)-\mathrm{O}(2), 1.354(4)$; $\mathrm{C}(3)-\mathrm{C}(4), 1.413(4) ; \mathrm{C}(3)-\mathrm{O}(5), 1.379(4) ; \mathrm{C}(4)-\mathrm{C}(6), 1.369(4) ; \mathrm{C}(5)-\mathrm{S}(1)$, 1.735(3); C(6)-S(1), 1.736(3); C(7)-C(8), 1.203(4); C(12)-C(13), 1.214(4); $\mathrm{C}(5)-\mathrm{C}(7)-\mathrm{C}(8), 178.5(4) ; \mathrm{C}(7)-\mathrm{C}(8)-\mathrm{Si}(1), 171.9(3) ; \mathrm{C}(6)-\mathrm{C}(12)-\mathrm{C}(13)$, 176.0(3); C(12)-C(13)-Si(2), 172.0(3).
$(\mathrm{Me}) \mathrm{C}-\mathrm{Si}-\mathrm{C}(\mathrm{Me})$ angles (average $110.63^{\circ}$ ) are slightly larger than the $(\equiv \mathrm{C}) \mathrm{C}-\mathrm{Si}-\mathrm{C}(\mathrm{Me})$ angles (average $108.27^{\circ}$ ), and the geometry around $\mathrm{Si}$ is distorted tetrahedral. The $\mathrm{C}-\mathrm{C}$ bond lengths within the central EDOT ring are in the range 1.369(4)-1.494(4) A, and reflect the expected single, $\mathrm{C}(1)-\mathrm{C}(2)$, and partial multiple bond character. The two $\mathrm{S}-\mathrm{C}$ bond lengths are not significantly different at 1.736(3) $\AA$, and the four C-O distances average 1.404(5) $\AA$. The thiophene ring is essentially planar with a maximum deviation from the ring plane of $0.014 \AA$ for $\mathrm{C}(4)$. The ethylenedioxy unit has a total puckering parameter of $0.490(4) \AA, q_{2}$ of $0.384(3), q_{3}$ of $0.304(3)$ and $\phi_{2}$ of $-86.4(4)^{\circ}$, consistent with a distorted half-chair conformation. ${ }^{24}$ All these parameters are not significantly different from those reported in several structures that contain EDOT ring systems. $^{25}$

The 1a molecules are packed into double-stranded columns along the $\left(\begin{array}{lll}1 & 0 & 0\end{array}\right)$ direction. The two strands of these columns are connected by two weak $\mathrm{C}-\mathrm{H}$... O hydrogen bonds. One, between the ethylenedioxy oxygen acceptor atom, $\mathrm{O}(1)$, and an ethylenedioxy hydrogen donor, $\mathrm{H}(1 \mathrm{a})$, on a molecule related by the symmetry operation $2-x,-y, 1-z(\mathrm{O}(1) \ldots \mathrm{H}(1 \mathrm{a}), 2.68(3)$ $\AA$; $\left.\mathrm{C}(1)-\mathrm{H}(1), 0.86(3) \AA ; \mathrm{O}(1) \ldots \mathrm{H}(1 \mathrm{a})-\mathrm{C}(1), 141(2)^{\circ}\right)$. This interaction forms a co-operative pair of hydrogen bonds across a crystallographic centre of symmetry. The second hydrogen bond involves the other ethylenedioxy oxygen atom, $\mathrm{O}(2)$, and a methyl hydrogen atom, $\mathrm{H}(10 \mathrm{~b})$, on a molecule related by the symmetry operation $1-x,-y, 1-z$. Here the hydrogen bond parameters are $\mathrm{O}(2) \ldots \mathrm{H}(10 \mathrm{~b}), 2.45(5) \AA, \mathrm{C}(10)-\mathrm{H}(10 \mathrm{~b}), 1.00(5)$ and $\mathrm{O}(2) \ldots \mathrm{H}(10 \mathrm{~b})-\mathrm{C}(10) 149(4)^{\circ}$.

In the crystal structure of $\left[(\mathrm{Ph})\left(\mathrm{PEt}_{3}\right)_{2} \mathrm{Pt}-\mathrm{C} \equiv \mathrm{C}\right.$-(EDOT)$\left.\mathrm{C} \equiv \mathrm{C}-\mathrm{Pt}\left(\mathrm{PEt}_{3}\right)_{2} \mathrm{Ph}\right] \mathbf{1 M}$ the asymmetric unit contains one unique dimetallic fragment the structure of which is shown in Fig. 2 which also contains a selection of relevant bond parameters. The structure is closely related to the previously reported "rigid

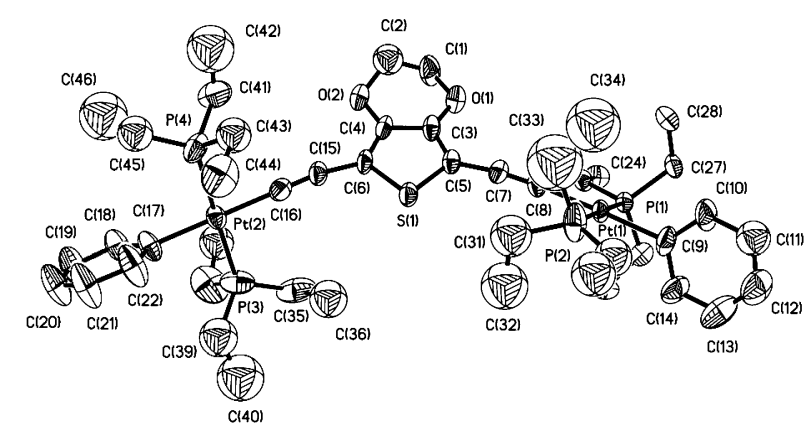

Fig. 2 The molecular structure of $\left[(\mathrm{Ph})\left(\mathrm{PEt}_{3}\right)_{2} \mathrm{Pt}-\mathrm{C} \equiv \mathrm{C}-\right.$ (EDOT) $\left.-\mathrm{C}=\mathrm{C}-\mathrm{Pt}\left(\mathrm{PEt}_{3}\right)_{2} \mathrm{Ph}\right] \mathbf{1 M}$ with displacement ellipsoids drawn at the $50 \%$ probability level and hydrogen atoms omitted for clarity. Selected bond lengths $(\AA)$ and angles $\left({ }^{\circ}\right)$ : $\mathrm{Pt}(1)-\mathrm{C}(8), 2.023(8)$; $\mathrm{Pt}(1)-\mathrm{C}(9)$, 2.061(9); $\quad \mathrm{Pt}(1)-\mathrm{P}(1), \quad 2.289(2) ; \quad \mathrm{Pt}(1)-\mathrm{P}(2), \quad 2.286(3) ; \quad \mathrm{Pt}(2)-\mathrm{C}(16)$, 2.032(10); $\mathrm{Pt}(2)-\mathrm{C}(17), \quad 2.062(9) ; \quad \mathrm{Pt}(2)-\mathrm{P}(3), \quad 2.279(3) ; \quad \mathrm{Pt}(2)-\mathrm{P}(4)$, 2.287(3); $\mathrm{C}(7)-\mathrm{C}(8), \quad 1.194(11) ; \quad \mathrm{C}(15)-\mathrm{C}(16), 1.201(12) ; \quad \mathrm{C}(1)-\mathrm{O}(1)$, $1.399(12) ; \quad \mathrm{C}(1)-\mathrm{C}(2), \quad 1.419(17) ; \quad \mathrm{C}(2)-\mathrm{O}(2), \quad 1.455(14), \quad \mathrm{C}(3)-\mathrm{O}(1)$, 1.364(11); $\mathrm{C}(3)-\mathrm{C}(5), \quad 1.387(12) ; \quad \mathrm{C}(3)-\mathrm{C}(4), \quad 1.415(11) ; \quad \mathrm{C}(4)-\mathrm{O}(2)$, 1.367(10); C(4)-C(6), 1.380(13); C(5)-C(7), 1.424(11); C(5)-S(1), 1.732(9); $\mathrm{C}(6)-\mathrm{S}(1), 1.742(8) ; \mathrm{C}(8)-\mathrm{Pt}(1)-\mathrm{C}(9), 178.1(4)$; C(8)-Pt(1)-P(2), 88.1(3); C(9)-Pt(1)-P(2), 91.2(3); $\quad$ C(8)-Pt(1)-P(1), 92.7(3); C(9)-Pt(1)-P(1), 87.9(3); $\quad \mathrm{P}(2)-\mathrm{Pt}(1)-\mathrm{P}(1), \quad 178.82(11) ; \quad \mathrm{C}(16)-\mathrm{Pt}(2)-\mathrm{C}(17), \quad 179.6(4) ;$ C(16)-Pt(2)-P(3), 91.4(3); C(17)-Pt(2)-P(3), 88.9(3); C(16)-Pt(2)-P(4), 86.9(3); C(17)-Pt(2)-P(4), 92.8(3); P(3)-Pt(2)-P(4), 178.04(12). 
rod" diplatinum di-yne complexes with the general formula trans$\left[(\mathrm{Ph})\left(\mathrm{R}_{3} \mathrm{P}\right)_{2} \mathrm{Pt}-\mathrm{C} \equiv \mathrm{C}-\mathrm{X}-\mathrm{C} \equiv \mathrm{C}-\mathrm{Pt}\left(\mathrm{PR}_{3}\right)_{2}(\mathrm{Ph})\right]$, where $\mathrm{R}=\mathrm{Et}$ or ${ }^{{ }_{-}}$ $\mathrm{Bu}$ and $\mathrm{X}=\mathrm{C}_{6} \mathrm{H}_{4},\left(\mathrm{C}_{4} \mathrm{H}_{2} \mathrm{~S}\right)$ and related derivatives. ${ }^{12,17,20,26}$ The two $\mathrm{PtC}_{2} \mathrm{P}_{2}$ units are planar and the bond parameters associated with the platinum(II) centres are similar to previously reported values. The diheral angle between the $\mathrm{Pt}(1) \mathrm{P}(1) \mathrm{P}(2) \mathrm{C}(8) \mathrm{C}(9)$ and the thiophene ring plane, $\mathrm{C}(3) \mathrm{C}(4) \mathrm{C}(5) \mathrm{C}(6) \mathrm{S}(1)$, is $40.9^{\circ}$ while that between the thiophene ring and $\operatorname{Pt}(2) \mathrm{P}(3) \mathrm{P}(4) \mathrm{C}(16) \mathrm{C}(17)$ is $63.8^{\circ}$ in such an orientation that the resultant dihedral angle between the two Pt square planes is $90.7^{\circ}$. The acetylinic units show small deviations from linearity with $\mathrm{C}(5)-\mathrm{C}(7)-\mathrm{C}(8), 171.4(10)^{\circ}, \mathrm{Pt}(1)-$ $\mathrm{C}(8)-\mathrm{C}(7), 176.1(8)^{\circ}, \mathrm{C}(6)-\mathrm{C}(15)-\mathrm{C}(16), 170.5(10)^{\circ}$, and $\mathrm{Pt}(2)-$ $\mathrm{C}(16)-\mathrm{C}(15), 178.9(9)^{\circ}$. The bond parameters within the central EDOT ring are similar to those found in the structure of 1a and, again, the thiophene ring shows slight deviations from planarity with the maximum deviation from the plane being $0.013 \AA$ A for $C(4)$. The ethylenedioxy ring adopts a distorted half chair conformation with a total puckering parameter of $0.407(6) \AA, q_{2}$ of $0.333(4), q_{3}$ of $0.233(4)$ and $\phi_{2}$ of $53.3(6)^{\circ}$.

An analysis of the intermolecular interactions in the crystal structure of 1M shows no abnormally short intermolecular interactions. The shortest potential $\mathrm{C}-\mathrm{H}$... O hydrogen bond with a C-H .. O angle greater than $140^{\circ}$ is between one of the methyl hydrogen atoms and a ring oxygen atom in a molecule related by the symmetry operation $1-x, 1-y,-z$; the hydrogen bond parameters are $\mathrm{C}(38) \ldots \mathrm{O}(2) 3.65(1) \AA, \mathrm{H}(38 \mathrm{a}) \ldots \mathrm{O}(2) 2.91 \AA$ and $\mathrm{C}(38)-\mathrm{H}(38 \mathrm{a}) \ldots \mathrm{O}(2) 142^{\circ}$.

As with $1 \mathrm{M}$ the complex $\left[(\mathrm{Ph})\left(\mathrm{PEt}_{3}\right)_{2} \mathrm{Pt}-\mathrm{C} \equiv \mathrm{C}\right.$-(EDOT)(EDOT)- $\left.\mathrm{C} \equiv \mathrm{C}-\mathrm{Pt}\left(\mathrm{PEt}_{3}\right)_{2} \mathrm{Ph}\right] \mathbf{2} \mathbf{M}$ crystallises in space group $\mathrm{C} 2 / c$ but, in this case, the asymmetric unit contains only half the dimeric unit and there is a crystallographic centre of symmetry at the mid-point of the $\mathrm{C}(6)-\mathrm{C}(6 \mathrm{a})$ bond that links the two EDOT groups. The structure of the dimetallic molecule is shown in Fig. 3 which also contains a selection of relevant bond parameters. As with $\mathbf{1 M}$, the structure closely resembles that of a range of previously reported diplatinum di-yne complexes with various aromatic and heteroaromatic linker groups. ${ }^{12,17,20,26}$ The unique

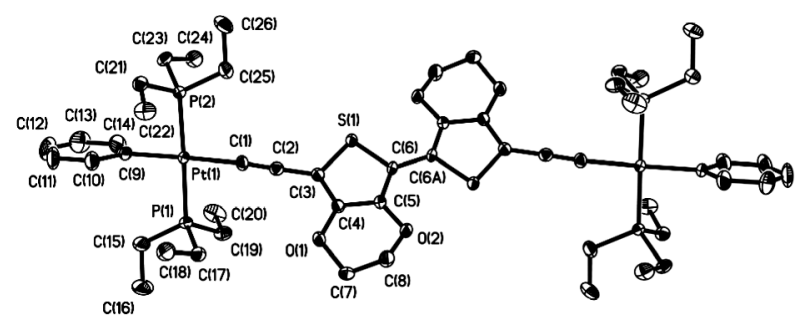

Fig. 3 The molecular structure of $\left[(\mathrm{Ph})\left(\mathrm{PEt}_{3}\right)_{2} \mathrm{Pt}-\right.$ $\mathrm{C} \equiv \mathrm{C}-($ EDOT $)-($ EDOT $\left.)-\mathrm{C} \equiv \mathrm{C}-\mathrm{Pt}\left(\mathrm{PEt}_{3}\right)_{2} \mathrm{Ph}\right] \mathbf{2 M}$ with displacement ellipsoids drawn at the $50 \%$ probability level and hydrogen atoms omitted for clarity. The disorder in the $\mathrm{C}(7)-\mathrm{C}(8)$ fragment is also omitted. Selected bond lengths $(\AA)$ and angles $\left({ }^{\circ}\right)$ : $\mathrm{Pt}(1)-\mathrm{C}(1), 2.037(3)$; $\mathrm{Pt}(1)-\mathrm{C}(9)$, 2.069(3); $\mathrm{Pt}(1)-\mathrm{P}(1), 2.2920$ (7); $\mathrm{Pt}(1)-\mathrm{P}(2), 2.2950(7) ; \mathrm{C}(1)-\mathrm{C}(2), 1.195(4)$; $\mathrm{C}(3)-\mathrm{S}(1), 1.752(3) ; \mathrm{C}(6)-\mathrm{S}(1), 1.742(3) ; \mathrm{C}(3)-\mathrm{C}(4), 1.371(4) ; \mathrm{C}(4)-\mathrm{C}(5)$, 1.418(4); C(5)-C(6), 1.371(4); C(6)-C(6a), 1.446(5); C(4)-O(1), 1.374(3); $\mathrm{C}(5)-\mathrm{O}(2), 1.373(3) ; \mathrm{C}(7)-\mathrm{O}(1), 1.459(5) ; \mathrm{C}(8)-\mathrm{O}(2), 1.445(6) ; \mathrm{C}(7)-\mathrm{C}(8)$, 1.506(9); $\quad \mathrm{C}(1)-\mathrm{Pt}(1)-\mathrm{C}(9), \quad$ 177.13(11); $\quad \mathrm{C}(1)-\mathrm{Pt}(1)-\mathrm{P}(1), \quad 86.46(9) ;$ C(9)-Pt(1)-P(1), 91.52(8); C(1)-Pt(1)-P(2), 94.14(9); C(9)-Pt(1)-P(2), 88.02(8); $\mathrm{P}(1)-\mathrm{Pt}(1)-\mathrm{P}(2), 175.75(3)$. The atom denoted " $\mathrm{C}(6 \mathrm{a})$ " is related to atom $\mathrm{C}(6)$ by the symmetry operation $-x, y, 0.5-z$.
$\mathrm{Pt}(\mathrm{II})$ centre adopts the expected square planar geometry and the Pt1C1C9P1P2 plane makes a diheral angle of $46.2^{\circ}$ with the plane of the unique thiophene ring ( 3 C4C5C6S1); a value within $6^{\circ}$ of that found in $\mathbf{M M}$. The two thiophene rings in the bi $(3,4-$ ethylenedioxythiophene) spacer group are necessarily coplanar by crystallographic symmetry. The intramolecular $\mathrm{S}(1) \ldots \mathrm{O}(1 \mathrm{a})$ distance is 2.938(3) $\AA$, which is significantly shorter than the sum of the van der Waals distances and has previously been taken as being indicative of a strong intramolecular interaction. ${ }^{27}$ Unlike the structures of 1a amd $\mathbf{1 M}$, the ethylenedioxy ring displays disorder with two orientations of the $\mathrm{C}(7)$ and $\mathrm{C}(8)$ atoms. However, the ring conformation can still be described as a half-chair. The bond parameters within the unique EDOT fragment closely resemble those in 1a, 1M and in a series of bi(3,4-ethylenedioxythiophene)containing compounds. ${ }^{27,28}$ The "rigid-rod" nature of the complex is again confirmed by the near linear acetylene unit; $\mathrm{C}(2)-\mathrm{C}(1)-$ $\mathrm{Pt}(1), 176.0(3)^{\circ} ; \mathrm{C}(1)-\mathrm{C}(2)-\mathrm{C}(3), 177.9(3)^{\circ}$.

In the crystal packing of $\mathbf{2} \mathbf{M}$ there are no particularly short intermolecular interactions. The only significant hydrogen bond is between a methyl hydrogen and one of the and a ring oxygen atoms in a molecule related by the symmetry operation $x, y, z$

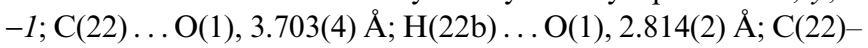
$\mathrm{H}(22 \mathrm{~b}) \ldots \mathrm{O}(1), 151.2(2)^{\circ}$.

\section{Thermal analysis}

All samples analysed under a dinitrogen atmosphere exhibit an exotherm coincident with mass loss due to decomposition. Decomposition onset was defined as a mass loss of $2 \%$. The peak decomposition temperature was defined as the first inflection point in the thermogravimetric curve, corresponding to a peak in the derivative of the TG data. The decomposition exotherms are broad with multiple peaks, and the TG curves suggest a stepwise decomposition process. The first step can be assigned to the removal of trialkylphosphine groups from the $\mathrm{Pt}(\mathrm{II})$ di-ynes and poly-ynes. TG traces show that $\mathbf{1 M - 2 M}$ and $\mathbf{1 P}-2 \mathbf{P}$ have decomposition temperatures of over $400{ }^{\circ} \mathrm{C}$, indicative of excellent thermal stability. These results are quite encouraging as they allow for the use of high temperature $T$ sealing procedures in device fabrication. The DTA peaks show exotherms at these temperatures, indicating that decomposition rather than vaporization is being observed. The results are shown in Table 1. The results indicate that the platinum(II) di-ynes and poly-ynes containing the EDOT spacers exhibit significantly higher thermal stability compared to those with fused and nonfused oligothiophene spacers, ${ }^{12}$ possibly because the ethylenedioxy groups encourage stronger inter-chain van der Waals bonding. The poly-yne $\mathbf{2 P}$ exhibits higher onset and peak decomposition temperatures than $\mathbf{1 P}$; similarly the di-yne $\mathbf{2} \mathbf{M}$ shows higher onset and peak decomposition temperatures than $\mathbf{1 M}$. Thus both the

Table 1 Thermal analysis results for decomposition temperatures: all temperatures in ${ }^{\circ} \mathrm{C}$. Uncertainties are approximately $\pm 8^{\circ} \mathrm{C}$

\begin{tabular}{lll}
\hline Compound & $T_{\text {decomp }}$ (onset) ${ }^{\circ} \mathrm{C}$ & $T_{\text {decomp }}$ (peak) ${ }^{\circ} \mathrm{C}$ \\
\hline $\mathbf{1 M}$ & 392 & 426 \\
2M & 398 & 432 \\
1P & 382 & 418 \\
2P & 391 & 422 \\
\hline
\end{tabular}


Table 2 Optical gap of 1M-2M, 1P-2P and other related compounds

\begin{tabular}{ll}
\hline Compound & Optical gap (eV) \\
\hline $\mathbf{1 M}$ & 3.00 \\
$\mathbf{2 M}$ & 2.70 \\
$\mathbf{1 P}$ & 2.70 \\
$\mathbf{2 P}$ & 2.50 \\
Pt-thiophene di-yne & 3.14 \\
Pt-thiophene poly-yne & 2.86 \\
Pt-bithiophene di-yne ${ }^{32}$ & 2.84 \\
Pt-bithiophene poly-yne $^{12}$ & 2.55 \\
Pt-thienothiophene di-yne $^{12}$ & 3.02 \\
Pt-thienothiophene poly-yne $^{12}$ & 2.78 \\
\hline
\end{tabular}

di-ynes and the poly-ynes exhibit increasing thermal stability with increasing size of the spacer group in the backbone. The di-ynes 1M-2M exhibit slightly higher onset and peak decomposition temperatures than the corresponding poly-ynes 1P-2P. A similar trend in thermal stability was previously observed among related platinum(II) di-ynes and poly-yne compounds. ${ }^{20}$

\section{Optical absorption spectroscopy}

Optical absorption and emission spectra taken in thin films are shown in Fig. 4. The first absorption band of $\mathbf{1 P}$ peaking at $2.90 \mathrm{eV}$ has its origin in the $\pi-\pi^{*}$ transitions of the conjugated polymer backbone and is associated with the first singlet excited state $\mathrm{S}_{1}{ }^{29}$ This band is red-shifted to $2.65 \mathrm{eV}$ in $\mathbf{2 P}$, indicating a more conjugated backbone along the polymer chain. The optical gaps (i.e., the onset of absorptions) of $\mathbf{1 M - 2 M}, \mathbf{1 P}-\mathbf{2 P}$ and related materials are shown in Table 2. The energy of the optical gap of both the di-ynes and poly-ynes decreases in going from EDOT to the bis-EDOT linker unit. We attribute the reduction in optical gap to an increased delocalization of $\pi$ electrons through the more conjugated bis-EDOT spacer along the polymer backbone. The optical gaps of the poly-ynes are lowered compared to the corresponding di-ynes, indicating that the $\pi$ conjugation of the ligand extends into and through the metal centre. This finding is consistent with our previous results on related systems. ${ }^{12,20}$

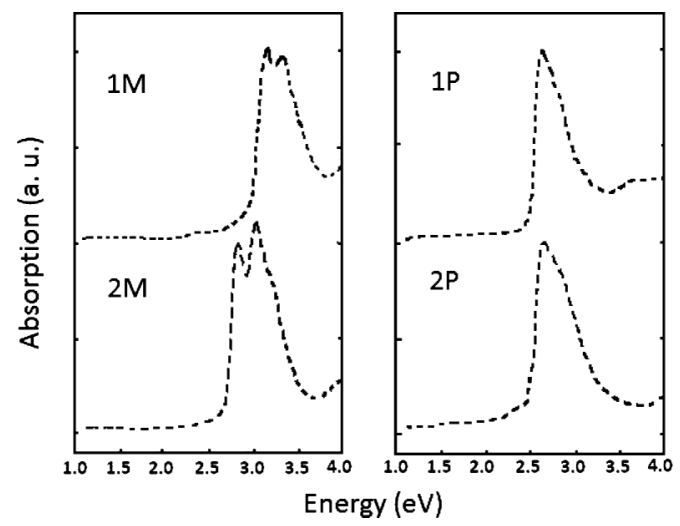

Fig. 4 Optical absorption spectra of $\mathrm{Pt}(\mathrm{II})$ di-ynes and poly-ynes $(\mathbf{1}=\mathbf{1} \mathbf{M}$, $\mathbf{2}=\mathbf{1 P}, \mathbf{3}=\mathbf{2} \mathbf{M}$ and $\mathbf{4}=\mathbf{2 P}$ ) taken at room temperature.

The optical gap of $\mathbf{1 P}$ is $2.70 \mathrm{eV}$, which compares to the gap of $2.86 \mathrm{eV}$ observed for the corresponding polymer containing the thiophene spacer group, and represents a red-shift of $0.16 \mathrm{eV}$. The optical gap of $\mathbf{2} \mathbf{P}$ is $2.50 \mathrm{eV}$, which compares to gaps of 2.55 and $2.78 \mathrm{eV}$, observed for the corresponding polymers containing the related non-fused and fused oligothiophene spacer groups, and represents a red-shift of $0.05 \mathrm{eV}$ and $0.28 \mathrm{eV}$, respectively. Similarly, the optical gaps of the di-ynes $\mathbf{1 M}-\mathbf{2} \mathbf{M}$ are lower compared to their counterparts containing the non-fused and fused thiophene systems. ${ }^{12,30,31}$ Thus the electron-rich EDOT spacers create stronger donor-acceptor interactions between the $\mathrm{Pt}$ (II) centres and conjugated ligands compared to their non-fused and fused counterparts.

\section{Conclusions}

In summary, the present work has demonstrated that it is possible to synthesize acetylide-functionalized heterocyclic ligands based on EDOT spacer groups and incorporate them into platinum(II) di-ynes and poly-ynes, by CuI catalysed dehydrohalogenation and polycondensation reaction respectively. Dinuclear platinum(II) complexes as well as polymeric materials with molar masses in the range of 40,000-52,000 $\mathrm{gmol}^{-1}$ containing EDOT and bis-EDOT spacer groups have been characterised by spectroscopic methods. Attempts have been made to evaluate how the EDOT linker units would influence the structural, thermal and optical properties of the dimeric and polymeric organoplatinum(II) compounds. The results of optical absorption measurements reveal that the electronrich EDOT spacers create stronger donor-acceptor interactions between the platinum(II) centres and conjugated ligands compared to the non-fused and fused oligothiophene counterparts. The EDOT spacer groups also have a significant effect on the thermal stability of the dimeric as well as polymeric platinum(II) complexes. The improved properties of the new materials have stimulated a study of organometallic polymers containing a variety of hybrid spacer groups based on EDOT systems and further investigation of other properties (such as redox and photovoltaic properties) of these $\pi$-conjugated organometallic systems and their organic analogues are in progress.

\section{Experimental}

\section{General procedures}

All reactions were performed under a dry nitrogen atmosphere using standard Schlenk or glove box techniques. ${ }^{33}$ Solvents were pre-dried and distilled before use by standard procedures. ${ }^{34}$ All chemicals, except where stated otherwise, were obtained from Sigma Aldrich and used as received. The compounds trans$\left[(\mathrm{Ph})\left(\mathrm{PEt}_{3}\right)_{2} \mathrm{PtCl}\right]{ }^{35}$ trans- $\left[\left(\mathrm{P}^{\mathrm{n}} \mathrm{Bu}_{3}\right)_{2} \mathrm{PtCl}_{2}\right],{ }^{35}$ 2,2'-bis-EDOT ${ }^{36}$ and $2,2^{\prime}, 5^{\prime}, 2^{\prime \prime}$-ter-EDOT ${ }^{37}$ were prepared by adaptation of literature procedures. The NMR spectra were recorded on a Bruker WM250 or AM- 400 spectrometer in $\mathrm{CDCl}_{3}$. The ${ }^{1} \mathrm{H}$ and ${ }^{13} \mathrm{C}\left\{{ }^{1} \mathrm{H}\right\}$ NMR spectra were referenced to solvent resonances and ${ }^{31} \mathrm{P}\left\{{ }^{1} \mathrm{H}\right\} \mathrm{NMR}$ spectra were referenced to external trimethylphosphite. IR spectra were recorded as $\mathrm{CH}_{2} \mathrm{Cl}_{2}$ solutions, in a $\mathrm{NaCl}$ cell, on a PerkinElmer 1710 FT-IR spectrometer, mass spectra on a Kratos MS 890 spectrometer by the electron impact (EI) and fast atom bombardment (FAB) techniques. Microanalyses were performed in the Department of Chemistry, University of Bath. Preparative TLC was carried out on commercial Merck plates with a $0.25 \mathrm{~mm}$ layer of silica. Column chromatography was performed either 
on Kieselgel 60 (230-400 mesh) silica gel or alumina (Brockman Grade II-III).

\section{Molecular weight measurements}

Molar masses were determined by GPC method ${ }^{38}$ using two PL Gel $30 \mathrm{~cm}, 5$ micron mixed C columns at $30 \mathrm{C}$ running in THF at 1 $\mathrm{cm}^{3} \mathrm{~min}^{-1}$ with a Roth Mocel 200 high precision pump. A DAWN DSP (Wyatt Technology) Multi-Angle Laser Light Scattering (MALLS) apparatus with 18 detectors and auxiliary Viscotek model 200 differential refractometer/viscometer detectors was used to calculate the molecular weights (referred to as GPC LS).

\section{Optical spectroscopy}

The dimeric and polymeric platinum(II) complexes were dissolved in dichloromethane. Thin films were prepared on quartz substrates using a conventional photoresist spin-coater. Typical film thicknesses were $100-150 \mathrm{~nm}$ as measured on a Dektak profilometer. The optical absorption spectra were measured with a HewlettPackard ultraviolet-visible (UV-VIS) spectrometer. Measurements of photoluminescence (PL) were made with the sample in a continuous-flow helium cryostat. The temperature was controlled with an Oxford-Intelligent temperature controller-4 (ITC-4) and was measured adjacent to the sample with a calibrated silicon diode. For PL measurements, excitation was provided from a continuous wave (cw) argon ion laser. The UV lines (334-365 nm) of this laser were used for the compounds with benzene and naphthalene spacers and $488 \mathrm{~nm}$ was used for the compounds with the anthracene spacer. Typical intensities used were a few $\mathrm{mW}$ $\mathrm{mm}^{-2}$. The emission spectra were recorded using a spectrograph with an optical fibre input coupled to a cooled charge coupled device (CCD) array (Oriel Instaspec IV).

\section{Thermal analysis}

Thermal analysis (differential thermal analysis, DTA, and thermogravimetry, TG) was performed simultaneously in a Stanton-
Redcroft model STA-780 Simultaneous Thermal Analyser under flowing $\mathrm{N}_{2}$. Sample masses were $\sim 1 \mathrm{mg}$ packed with $\sim 1 \mathrm{mg} \mathrm{Al}_{2} \mathrm{O}_{3}$ in open Inconel crucibles. The reference crucible contained $\mathrm{Al}_{2} \mathrm{O}_{3}$. Samples were heated at $10^{\circ} \mathrm{C} \mathrm{min}^{-1}$ to $485^{\circ} \mathrm{C}$. The thermocouple readings were calibrated using a series of DTA standard materials: $\mathrm{KNO}_{3}$, In, $\mathrm{Sn}, \mathrm{Ag}_{2} \mathrm{SO}_{4}$, and $\mathrm{K}_{2} \mathrm{SO}_{4}$ as well as $\mathrm{Pb}$ and $\mathrm{Al}$ as secondary standards, using the same heating rates as the samples.

\section{X-ray crystallography}

Data for 1a and 1M were collected on a Bruker Nonius Kappa CCD diffractometer equipped with an Oxford Cryostream crystal cooling apparatus, and using graphite monochromater Mo-K $\alpha$ radiation. Data for $\mathbf{2 M}$ was collected on Station 9.8 at the SRS Daresbury synchrotron facility using a Bruker APEX II diffractometer, also equipped with an Oxford Cryosystems crystal cooling device. In all cases semi-empirical absorption corrections based on inerframe scaling were applied. The structures were solved using direct methods (SIR92 ${ }^{39}$ ) and from subsequent Fourier difference syntheses. The structures were refined by fullmatrix least-squares on $F^{2}$ (SHELXL 9740). For 1a the hydrogen atoms were located in the electron density difference map and were allowed to refine freely. For $\mathbf{1 M}$ and $\mathbf{2 M}$ the hydrogen atoms were placed in geometrically-idealised positions and refined using a riding model. In $\mathbf{1 M}$ some of the ethyl groups displayed a tendency to disorder, but the best refinement model was obtained by using single sites with the carbon atoms assigned isotropic displacement parameters. In $2 \mathrm{M}$ the $\mathrm{C}(7)$ and $\mathrm{C}(8)$ atoms in the EDOT ligand showed positional disorder over two sites. The pairs of atoms were refined with the occupancies summed to unity. The refinements were continued until convergence was reached, and in the final cycles of refinement weighting schemes were introduced which produced relatively flat analyses of variance. Crystal data and refinement details are summarsied in Table 3.

Table 3 Crystal data and refinement parameters for $\mathbf{1 a}, \mathbf{1 M}$ and $\mathbf{2 M}$

\begin{tabular}{|c|c|c|c|}
\hline Compound reference & $1 \mathbf{a}$ & $1 \mathrm{M}$ & $2 \mathrm{M}$ \\
\hline Chemical formula & $\mathrm{C}_{16} \mathrm{H}_{22} \mathrm{O}_{2} \mathrm{SSi}_{2}$ & $\mathrm{C}_{46} \mathrm{H}_{74} \mathrm{O}_{2} \mathrm{P}_{4} \mathrm{Pt}_{2} \mathrm{~S}$ & $\mathrm{C}_{52} \mathrm{H}_{78} \mathrm{O}_{4} \mathrm{P}_{4} \mathrm{Pt}_{2} \mathrm{~S}_{2}$ \\
\hline Formula mass & 334.58 & 1205.17 & 1345.32 \\
\hline Crystal system & Monoclinic & Monoclinic & Monoclinic \\
\hline$a / \AA$ & $7.3848(4)$ & $31.8940(3)$ & $42.980(4)$ \\
\hline$b / \AA$ & $27.2437(12)$ & $9.6610(1)$ & $13.4875(13)$ \\
\hline$c / \AA$ & $9.4632(6)$ & $33.6030(4)$ & $9.8161(9)$ \\
\hline$\beta\left({ }^{\circ}\right)$ & $99.407(2)$ & $103.240(1)$ & $101.078(1)$ \\
\hline Unit cell volume $/ \AA^{3}$ & $1878.29(18)$ & $10078.8(2)$ & $5584.3(9)$ \\
\hline$T / \mathrm{K}$ & $150(2)$ & $150(2)$ & $150(2)$ \\
\hline Space group & $P 2_{1} / a$ & $C 2 / c$ & $C 2 / c$ \\
\hline No. of formula units per unit cell, $Z$ & 4 & 8 & 4 \\
\hline Radiation type & Mo-K $\alpha$ & Mo-K $\alpha$ & Synchrotron \\
\hline Wavelength, $\lambda / \AA$ & 0.71073 & 0.71073 & 0.6775 \\
\hline Absorption coefficient, $\mu / \mathrm{mm}^{-1}$ & 0.301 & 5.748 & 4.446 \\
\hline No. of reflections measured & 11695 & 39442 & 31903 \\
\hline No. of independent reflections & 4099 & 9063 & 8384 \\
\hline$R_{\text {int }}$ & 0.0583 & 0.0602 & 0.0978 \\
\hline Final $R_{1}$ values $(I>2 \sigma(I))$ & 0.0599 & 0.0490 & 0.0283 \\
\hline Final $w R\left(F^{2}\right)$ values $(I>2 \sigma(I))$ & 0.1168 & 0.1194 & 0.0722 \\
\hline Final $R_{1}$ values (all data) & 0.1101 & 0.0645 & 0.0325 \\
\hline Final $w R\left(F^{2}\right)$ values (all data) & 0.1406 & 0.1287 & 0.0738 \\
\hline Goodness of fit on $F^{2}$ & 1.050 & 1.043 & 0.976 \\
\hline
\end{tabular}




\section{Ligand synthesis}

The ligand precursors were synthesized by following a general procedure outlined below for $\mathbf{1 a}$ and $\mathbf{1 b}$.

2,5-Diiodo-3,4-ethylenedioxythiophene 1. A solution of 3,4ethylenedioxythiophene $(2.8 \mathrm{~g}, 20.0 \mathrm{mmol})$ and iodine monochloride-pyridine complex $(11.5 \mathrm{~g}, 45.0 \mathrm{mmol})$ in dichloromethane $(75 \mathrm{~mL})$ was stirred at room temperature for $1 \mathrm{~h}$ during which time a precipitate of pyridinium salt was produced. The precipitate was removed by filtration and the filtrate was removed under reduced pressure. The solid residue was rinsed with a mixture of water/methanol $(1: 1)$ and it was recrystallized twice from propanone. The product was obtained as greenishwhite crystals $(7.4 \mathrm{~g}, 93 \%)$. ${ }^{1} \mathrm{HNMR}\left(400 \mathrm{MHz}, \mathrm{CDCl}_{3}\right): \delta=4.24$ $\operatorname{ppm}\left(\mathrm{s}, 4 \mathrm{H}, \mathrm{H}_{\mathrm{EDOT}}\right) .{ }^{13} \mathrm{C} \mathrm{NMR}\left(100.6 \mathrm{MHz}, \mathrm{CDCl}_{3}\right): \delta 54.08\left(\mathrm{CH}_{2}\right)$, 64.84 (C2,5), $143.84(\mathrm{C} 3,4)$, and EI-MS: $m / z 393.7\left(M^{+}\right)$.

2,5-Bis(trimethylsilylethynyl)-3,4-ethylenedioxythiophene 1 a. To a deoxygenated solution of $\mathbf{1}(1.50 \mathrm{~g}, 3.80 \mathrm{mmol})$ in ${ }^{i} \mathrm{Pr}_{2} \mathrm{NH}-$ THF $(50 \mathrm{~mL}, 1: 1(\mathrm{v} / \mathrm{v}))$ under $\mathrm{N}_{2}$ was added a catalytic mixture of $\mathrm{CuI}(12 \mathrm{mg}), \mathrm{Pd}(\mathrm{OAc})_{2}(11 \mathrm{mg})$ and $\mathrm{PPh}_{3}(65 \mathrm{mg})$. The solution was stirred for $10 \mathrm{~min}$ at room temperature and then trimethylsilylethyne $(0.93 \mathrm{~g}, 9.5 \mathrm{mmol})$ was added. The reaction temperature was then raised to $40{ }^{\circ} \mathrm{C}$ and the reaction was left with stirring for $2 \mathrm{~h}$. The reaction mixture was then allowed to cool down to room temperature, filtered and the solvent mixture was removed. The solid residue was purified by silica column chromatography eluting with $\mathrm{CH}_{2} \mathrm{Cl}_{2} /$ hexane $(1: 2 \mathrm{v} / \mathrm{v})$. The desired compound 1a was isolated as a light-yellow solid (1.1 g, $85 \%$ yield). IR $\left(\mathrm{CH}_{2} \mathrm{Cl}_{2}\right): v \mathrm{~cm}^{-1} 2141$ (-C $\left.\equiv \mathrm{C}-\right) .{ }^{1} \mathrm{H}$ NMR $\left(250 \mathrm{MHz}, \mathrm{CDCl}_{3}\right): \delta=0.20\left(\mathrm{~s}, 18 \mathrm{H}, \mathrm{H}_{\mathrm{Me}}\right), 4.24 \mathrm{ppm}(\mathrm{s}, 4 \mathrm{H}$, $\left.\mathrm{H}_{\mathrm{EDOT}}\right),{ }^{13} \mathrm{C} \mathrm{NMR}\left(100.6 \mathrm{MHz}, \mathrm{CDCl}_{3}\right): \delta 0.17\left(\mathrm{SiMe}_{3}\right), 64.4$ $\left(\mathrm{CH}_{2}\right), 94.2(\mathrm{C} 2,5), 99.97,103.1(\mathrm{C} \equiv \mathrm{C}), 143.8(\mathrm{C} 3,4)$, and EI-MS: $m / z$ 334.4 $\left(M^{+}\right)$. Calc. for $\mathrm{C}_{16} \mathrm{H}_{22} \mathrm{Si}_{2} \mathrm{O}_{2} \mathrm{~S}: \mathrm{C}, 57.44 ; \mathrm{H}, 6.63$; Found: C, 57.60; H, 6.70\%.

2,5-Bis(ethynyl)-3,4-ethylenedioxythiophene 1b. 1a (0.668 g, $2.00 \mathrm{mmol}$ ) was dissolved in $30 \mathrm{~mL}$ THF. $\mathrm{KOH}(0.25 \mathrm{~g}, 4.4 \mathrm{mmol})$ in water/methanol $(20 \mathrm{~mL}, 1: 3 \mathrm{v} / \mathrm{v})$ was added and the solution was stirred for one hour at room temperature. The solvent was then removed and the residue was dissolved in $\mathrm{CH}_{2} \mathrm{Cl}_{2}$ and subjected to a silica column chromatography. The desired compound was collected with the aid of hexane/dichloromethane $(1: 1 \mathrm{v} / \mathrm{v})$ to afford $\mathbf{1 b}$ as a colorless microcrystalline solid $(0.29 \mathrm{~g}, 78 \%$ yield $)$. $\mathrm{IR}\left(\mathrm{CH}_{2} \mathrm{Cl}_{2}\right): v \mathrm{~cm}^{-1} 2107$ (-C $\left.\equiv \mathrm{C}-\right), 3300(-\mathrm{C} \equiv \mathrm{C}-\mathrm{H}) .{ }^{1} \mathrm{HNMR}$ $\left(250 \mathrm{MHz}, \mathrm{CDCl}_{3}\right): \delta 3.4 \mathrm{ppm}\left(\mathrm{s}, 2 \mathrm{H}, \mathrm{H}_{\text {terminal }}\right), 4.20 \mathrm{ppm}(\mathrm{s}, 4 \mathrm{H}$, $\left.\mathrm{H}_{\mathrm{EDOT}}\right) .{ }^{13} \mathrm{C} \mathrm{NMR}\left(100.6 \mathrm{MHz}, \mathrm{CDCl}_{3}\right): \delta 64.5\left(\mathrm{CH}_{2}\right), 95.2(\mathrm{C} 2,5)$, 99.07, $106.23(\mathrm{C} \equiv \mathrm{C}), 144.4(\mathrm{C} 3,4)$ and EI-MS: $m / z 190.3\left(M^{+}\right)$. Calc. for $\mathrm{C}_{10} \mathrm{H}_{6} \mathrm{O}_{2} \mathrm{~S}$ : C, 63.14; H, 3.18; Found: C, 63.20; H, 3.00\%.

2,2'-Bis-(3,4-ethylenedioxythiophene). 3,4-Ethylenedioxythiophene $1(5.00 \mathrm{~g}, 0.036 \mathrm{~mol})$ in $170 \mathrm{~mL}$ THF was cooled to $-78^{\circ} \mathrm{C}$ under $\mathrm{N}_{2}$. ${ }^{n} \mathrm{BuLi}(1.6 \mathrm{M}, 0.036 \mathrm{~mol})$ was then added dropwise and the solution was stirred for $45 \mathrm{~min}$. After that $\mathrm{CuCl}_{2}(4.7 \mathrm{~g}$, $0.036 \mathrm{~mol}$ ) was added and the reaction mixture was left to stir at $40{ }^{\circ} \mathrm{C}$ for $2 \mathrm{~h}$. The solution was allowed to cool down to room temperature and the reaction was washed with water, solvent was removed and the solid residue was purified by silica column chromatography eluting with chloroform. The title compound was isolated as a white crystalline solid $(6.73 \mathrm{~g}, 68 \%$ yield $) .{ }^{1} \mathrm{H}$
NMR (250 MHz, $\left.\mathrm{CDCl}_{3}\right): \delta=4.27\left(\mathrm{~s}, 8 \mathrm{H}, \mathrm{H}_{\mathrm{EDOT}}\right), 6.83(\mathrm{~s}, 2 \mathrm{H}$, $\left.\mathrm{H}_{\text {terminal }}\right) .{ }^{13} \mathrm{C} \mathrm{NMR}\left(100.6 \mathrm{MHz}, \mathrm{CDCl}_{3}\right): \delta 139.8,85.5,64.9$. EI-MS: $m / z 282.3\left(M^{+}\right)$. Calc. for $\mathrm{C}_{12} \mathrm{H}_{10} \mathrm{~S}_{2} \mathrm{O}_{4}$ : C, 51.05; H, 3.57; Found: C, 51.4; H, 3.60\%.

5,5'-Diiodo-(2,2'-bis-3,4-ethylenedioxythiophene) 2. Similar method to the synthesis of $\mathbf{1}$ was applied but using 2,2'-bis(3,4-ethylenedioxythiophene) instead. The title compound was isolated as a dark-green crystalline solid in $85 \%$ yield. ${ }^{1} \mathrm{HNMR}$ $\left(250 \mathrm{MHz} \mathrm{CDCl}_{3}\right) \delta=4.27$ (s, 8H, $\left.\mathrm{H}_{\mathrm{EDOT}}\right) .{ }^{13} \mathrm{C} \mathrm{NMR}(100.6 \mathrm{MHz}$, $\left.\mathrm{CDCl}_{3}\right)$ : d 139.8, 85.5, 64.9. EI-MS: $m / z$ 534.1 $\left(M^{+}\right)$. Calc. for $\mathrm{C}_{12} \mathrm{H}_{8} \mathrm{~S}_{2} \mathrm{O}_{4} \mathrm{I}_{2}$ : C, 26.99; H, 1.51; Found: C, 27.09; H, 1.48\%.

5,5' - Bis(trimethylsilylethynyl)-2,2' - bis-3, 4-ethylenedioxythiophene 2a. Similar procedure to the synthesis of 1a was applied using 2 (1.50 g, $2.8 \mathrm{mmol})$. $2 \mathbf{a}$ was isolated as a pale yellow solid (1.1 g, 83\% yield). IR $\left(\mathrm{CH}_{2} \mathrm{Cl}_{2}\right): v \mathrm{~cm}^{-1} 2135$ (-C $\left.\equiv \mathrm{C}-\right) .{ }^{1} \mathrm{H}$ NMR $\left(250 \mathrm{MHz}, \mathrm{CDCl}_{3}\right): \delta 4.22 \mathrm{ppm}\left(\mathrm{s}, 8 \mathrm{H}, \mathrm{H}_{\mathrm{EDOT}}\right), 0.17 \mathrm{ppm}(\mathrm{s}, 18 \mathrm{H}$, $\left.\mathrm{H}_{\mathrm{Me}}\right) \cdot{ }^{13} \mathrm{C} \mathrm{NMR}\left(100.6 \mathrm{MHz}, \mathrm{CDCl}_{3}\right): \delta 139.0(\mathrm{C} 3,4), 85.2(\mathrm{C} 2,5)$ and $65.1\left(\mathrm{CH}_{2}\right), 106.23,92.07(\mathrm{C} \equiv \mathrm{C}), 0.17\left(\mathrm{SiMe}_{3}\right)$. EI-MS: $m / z$ $474.8\left(M^{+}\right)$. Calc. for $\mathrm{C}_{22} \mathrm{H}_{26} \mathrm{Si}_{2} \mathrm{O}_{4} \mathrm{~S}_{2}$ : C, 55.66; H, 5.52; Found: $\mathrm{C}$, $55.90 ; \mathrm{H}, 5.48 \%$.

5,5'-Bis(ethynyl)-2,2'-bis-3,4-ethylenedioxythiophene 2b. Similar procedure to that of $\mathbf{1 b}$ was applied using 2a (0.668 $\mathrm{g}$, $1.41 \mathrm{mmol}) . \mathbf{2 b}$ was isolated as a colorless microcrystalline solid (0.37 g, 80\% yield). IR( $\left.\mathrm{CH}_{2} \mathrm{Cl}_{2}\right): v \mathrm{~cm}^{-1} 2107$ (-C $\left.\equiv \mathrm{C}-\right), 3298$ $(-\mathrm{C} \equiv \mathrm{C}-\mathrm{H}) .{ }^{1} \mathrm{HNMR}\left(250 \mathrm{MHz}, \mathrm{CDCl}_{3}\right): \delta 4.24 \mathrm{ppm}$ (s, $\left.8 \mathrm{H}, \mathrm{H}_{\text {EDOT }}\right), 3.3 \mathrm{ppm}\left(\mathrm{s}, 2 \mathrm{H}, \mathrm{H}_{\text {terminal }}\right) .{ }^{13} \mathrm{C} \mathrm{NMR}(100.6 \mathrm{MHz}$, $\left.\mathrm{CDCl}_{3}\right): \delta 138.6(\mathrm{C} 3,4), 85.2(\mathrm{C} 2,5)$ and $64.5\left(\mathrm{CH}_{2}\right), 106.23,92.07$ $(\mathrm{C} \equiv \mathrm{C})$. EI-MS: $m / z 330.5\left(M^{+}\right)$. Calc. for $\mathrm{C}_{16} \mathrm{H}_{10} \mathrm{O}_{4} \mathrm{~S}_{2}: \mathrm{C}, 58.17$; H, 3.05; Found: C, 58.30; H, 3.20\%.

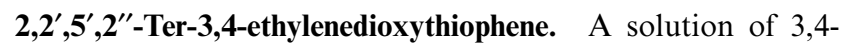
ethylenedioxythiophene $(1.33 \mathrm{~g}, 9.37 \mathrm{mmol})$ in $50 \mathrm{~mL}$ THF under nitrogen was cooled to $-78^{\circ} \mathrm{C}$ via a cooling bath. To the stirred pre-cooled solution, $(3.7 \mathrm{~mL}, 9.25 \mathrm{mmol})$ of ${ }^{n} \mathrm{BuLi}$ was added via syringe. After $45 \mathrm{~min}$ the reaction mixture was allowed to warm to $0{ }^{\circ} \mathrm{C}$, then $\mathrm{MgBr}_{2}$. $\mathrm{Et}_{2} \mathrm{O}(2.50 \mathrm{~g}, 9.68 \mathrm{mmol})$ was added in one portion. After $45 \mathrm{~min}, \mathrm{NiCl}_{2} \cdot \mathrm{dppp}(0.10 \mathrm{~g}, 0.187 \mathrm{mmol})$ was added followed by 2,5-diiodo-EDOT 1 (1.40 g, $3.56 \mathrm{mmol})$. The mixture was allowed to warm slowly to room temperature. The product was precipitated in water/pentane mixture and the title compound was isolated as a medium brown solid $(2.6 \mathrm{~g}, 65.5 \%) .{ }^{1} \mathrm{H}$ NMR (250 MHz, $\left.\mathrm{CDCl}_{3}\right): \delta=4.27$ (s, 4H, H-4,5); ${ }^{13} \mathrm{C} \mathrm{NMR}$ $\left(100.6 \mathrm{MHz}, \mathrm{CDCl}_{3}\right)$ : d $139.8(\mathrm{C} 3,4), 85.5(\mathrm{C} 2,5)$ and $64.9\left(\mathrm{CH}_{2}\right)$. EI-MS: $m / z 325\left(M^{+}\right)$.

$\mathbf{5 , 5 ^ { \prime \prime }}$-Diiodo $-\mathbf{2}, \mathbf{2}^{\prime}, \mathbf{5}^{\prime}, \mathbf{2}^{\prime \prime}$-ter-3,4-ethylenedioxythiophene 3. Similar method to the synthesis of 1 was applied using $2,2^{\prime}, 5^{\prime}, 2^{\prime \prime}$ ter-3,4-ethylenedioxythiophene. Dark-green crystalline solid (83\% yield). ${ }^{1} \mathrm{HNMR}\left(250 \mathrm{MHz}, \mathrm{CDCl}_{3}\right): \delta=4.300$ (br, $12 \mathrm{H}, \mathrm{H}_{\mathrm{EDOT}}$ ). ${ }^{13} \mathrm{C}$ NMR (100.6 MHz, $\mathrm{CDCl}_{3}$ ): d 140.3, 139.20, 131.10, 128.64, 124.63, 124.02, 92.07, 85.2, 64.5. EI-MS: $m / z$ 674.1 $\left(M^{+}\right)$. Calc. for $\mathrm{C}_{18} \mathrm{H}_{12} \mathrm{~S}_{3} \mathrm{O}_{6} \mathrm{I}_{2}$ : C, 32.06; H, 1.79; Found: C, 32.11; H, $1.83 \%$.

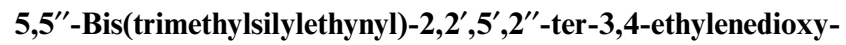
thiophene, 3a. Similar procedure to the synthesis of 1a was applied using $3(1.50 \mathrm{~g}, 2.23 \mathrm{mmol})$ instead. Pale yellow solid (1.1 g, 83\% yield). IR( $\left.\mathrm{CH}_{2} \mathrm{Cl}_{2}\right): v \mathrm{~cm}^{-1} 2135$ (-C $\left.\equiv \mathrm{C}-\right) .{ }^{1} \mathrm{HNMR}$ (250 MHz, CDCl3): d 4.28 ppm (s, 12H, $\left.\mathrm{H}_{\mathrm{EDOT}}\right), 0.16 \mathrm{ppm}(\mathrm{s}, 18 \mathrm{H}$, $\left.\mathrm{H}_{\mathrm{Me}}\right) .{ }^{13} \mathrm{C} \mathrm{NMR}\left(100.6 \mathrm{MHz}, \mathrm{CDCl}_{3}\right): \delta 139.0(\mathrm{C} 3,4), 85.0(\mathrm{C} 2,5)$ 
and $66.7\left(\mathrm{CH}_{2}\right), 105.0,91.0(\mathrm{C} \equiv \mathrm{C}), 0.22\left(\mathrm{SiMe}_{3}\right)$. EI-MS: $m / z$ $614.9\left(M^{+}\right)$. Calc. for $\mathrm{C}_{28} \mathrm{H}_{30} \mathrm{Si}_{2} \mathrm{O}_{6} \mathrm{~S}_{3}$ : C, 54.68; H, 4.93; Found: $\mathrm{C}$, $55.07 ; \mathrm{H}, 5.05 \%$.

5,5'-Bis(ethynyl)-2,2',5',2'-ter-3,4-ethylenedioxythiophene $\mathbf{3 b}$. Similar procedure to that of $\mathbf{1 b}$ was applied using 3a $(0.867 \mathrm{~g}$, $1.41 \mathrm{mmol}), \mathrm{KOH}(0.25 \mathrm{~g}, 4.4 \mathrm{mmol})$ in $\mathrm{THF} / \mathrm{methanol}(30 \mathrm{~mL}$, $5: 1, \mathrm{v} / \mathrm{v})$. The product decomposed to a black solid during workup and isolation.

\section{Synthesis of Pt(II) di-ynes}

trans- $\left[(\mathrm{Ph})\left(\mathrm{Et}_{3} \mathrm{P}\right)_{2} \mathrm{Pt}-\mathrm{C} \equiv \mathrm{C}-\mathrm{R}-\mathrm{C} \equiv \mathrm{C}-\mathrm{Pt}-\left(\mathrm{PEt}_{3}\right)_{2} \mathrm{Ph}\right][R=\mathbf{3 , 4}-$ ethylenedioxythiophene-2,5-diyl $1 \mathrm{M} . \quad \mathbf{1 b}(0.0448 \mathrm{~g}, 0.2358 \mathrm{mmol})$ and trans $-\left[\mathrm{Pt}\left(\mathrm{PEt}_{3} \mathrm{P}\right)_{2} \mathrm{Cl}_{2]}(0.2816 \mathrm{~g}, 0.5187 \mathrm{mmol})\right.$ were dissolved in $\mathrm{CH}_{2} \mathrm{Cl}_{2} /{ }^{i} \mathrm{Pr}_{2} \mathrm{NH}(50 \mathrm{~mL}, 1: 1, \mathrm{v} / \mathrm{v})$ under nitrogen. A catalytic amount of $\mathrm{CuI}(\sim 5 \mathrm{mg})$ was added and the solution was stirred at room temperature for $15 \mathrm{~h}$, after which all volatile components were removed under reduced pressure and the residue was dissolved in $\mathrm{CH}_{2} \mathrm{Cl}_{2}$, passed through a silica column eluting with hexane/ $\mathrm{CH}_{2} \mathrm{Cl}_{2}(1: 1, \mathrm{v} / \mathrm{v})$. Removal of the solvents under reduced pressure gave the title compound as a pale yellow solid (0.21 g, 75\%). IR $\left(\mathrm{CH}_{2} \mathrm{Cl}_{2}\right): v \mathrm{~cm}^{-1} 2080$ (C三C). ${ }^{1} \mathrm{H}$ NMR $\left(250 \mathrm{MHz} \mathrm{CDCl}_{3}\right): \delta=7.21 \mathrm{ppm}\left(\mathrm{d}, 4 \mathrm{H}, \mathrm{H}_{\text {ortho }}\right.$ of $\left.\mathrm{Ph}\right), 6.89 \mathrm{ppm}$ (dd, $4 \mathrm{H}, \mathrm{H}_{\text {meta }}$ of $\left.\mathrm{Ph}\right), 6.75 \mathrm{ppm}\left(\mathrm{dd}, 2 \mathrm{H}, \mathrm{H}_{\text {para }}\right.$ of $\mathrm{Ph}$ ), $4.20 \mathrm{ppm}$ (s, $4 \mathrm{H}, \mathrm{H}_{\mathrm{EDOT}}$ ), $1.65 \mathrm{ppm}\left(\mathrm{q}, 24 \mathrm{H}, \mathrm{H}_{\mathrm{P}-\mathrm{CH} 2}\right), 1.00 \mathrm{ppm}\left(\mathrm{t}, 36 \mathrm{H}, \mathrm{H}_{\mathrm{P}-\mathrm{CH}_{3}}\right)$. ${ }^{13} \mathrm{C} \mathrm{NMR}\left(100.6 \mathrm{MHz}, \mathrm{CDCl}_{3}\right): \delta 156.74,139.19,138.41,128.76$, 127.14, 122.47, 122.29 (Arom.) 107.95, $108.56(\mathrm{C} \equiv \mathrm{C}), 15.02,7.99$ (Et). ${ }^{31} \mathrm{P}\left\{{ }^{1} \mathrm{H}\right\} \mathrm{NMR}\left(100 \mathrm{MHz}, \mathrm{CDCl}_{3}\right): \delta-138.07,{ }^{1} J_{P t-P}=2645$ Hz. FAB-MS: $m / z 1205\left(M^{+}\right)$. Calc. for $\mathrm{C}_{46} \mathrm{H}_{74} \mathrm{SO}_{2} \mathrm{P}_{4} \mathrm{Pt}_{2}: \mathrm{C}$, 45.84; $\mathrm{H}, 6.19$. Found: C, 45.90; H, 6.30\%.

trans- $\left[(\mathbf{P h})\left(\mathrm{Et}_{3} \mathbf{P}\right)_{2} \mathrm{Pt}-\mathrm{C} \equiv \mathrm{C}-\mathrm{R}-\mathrm{C} \equiv \mathrm{C}-\mathrm{Pt}-\left(\mathrm{PEt}_{3}\right)_{2} \mathbf{P h}\right]\left[R=\mathbf{2}, \mathbf{2}^{\prime}-\right.$ bis-3,4-ethylenedioxythio-phene-5,5'-diyl) 2M. Similar procedure to the synthesis of $\mathbf{1 M}$ was applied using $\mathbf{2 b}(0.090 \mathrm{~g}$, $0.272 \mathrm{mmol})$, trans $-\left[\left(\mathrm{PEt}_{3}\right)_{2}(\mathrm{Ph}) \mathrm{PtCl}\right](0.50 \mathrm{~g}, 0.92 \mathrm{mmol})$ in ${ }^{i} \mathrm{Pr}_{2} \mathrm{NH} / \mathrm{CH}_{2} \mathrm{Cl}_{2}(50 \mathrm{~mL}, 1: 1 \mathrm{v} / \mathrm{v})$ and $\mathrm{CuI}(5 \mathrm{mg}) . \mathbf{1 M}$ was isolated as a pale yellow solid $(0.30 \mathrm{~g}, 58 \%$ yield $)$. $\mathrm{IR}\left(\mathrm{CH}_{2} \mathrm{Cl}_{2}\right): v \mathrm{~cm}^{-1} 2135$ $(-\mathrm{C} \equiv \mathrm{C}-) .{ }^{1} \mathrm{H}$ NMR $\left(250 \mathrm{MHz}, \mathrm{CDCl}_{3}\right): \delta 7.25 \mathrm{ppm}\left(\mathrm{d}, 4 \mathrm{H}, \mathrm{H}_{\text {ortho }}\right.$ of $\mathrm{Ph}$ ), $6.90 \mathrm{ppm}\left(\mathrm{dd}, 4 \mathrm{H}, \mathrm{H}_{\text {meta }}\right.$ of $\left.\mathrm{Ph}\right), 6.70 \mathrm{ppm}\left(\mathrm{dd}, 2 \mathrm{H}, \mathrm{H}_{\text {para }}\right.$ of $\mathrm{Ph}), 4.20 \mathrm{ppm}\left(\mathrm{s}, 8 \mathrm{H}, \mathrm{H}_{\text {EDOT }}\right), 1.65 \mathrm{ppm}\left(\mathrm{q}, 12 \mathrm{H}, \mathrm{H}_{\mathrm{P}-\mathrm{CH} 2}\right), 1.00 \mathrm{ppm}$ $\left(\mathrm{t}, 36 \mathrm{H}, \mathrm{H}_{\mathrm{P}-\mathrm{CH} 3}\right) .{ }^{13} \mathrm{C} \mathrm{NMR}\left(100 \mathrm{MHz}, \mathrm{CDCl}_{3}\right): \delta 140.4,139.4$, 127.7-119.6 (C-1 to 8 and $\mathrm{Ph} \mathrm{Cs}), 112.6(\mathrm{C} \equiv \mathrm{C}), 30.1\left(\mathrm{PCH}_{2}\right)$, $8.45\left(\mathrm{CH}_{3}\right) .{ }^{31} \mathrm{P}\left\{{ }^{1} \mathrm{H}\right\}$ NMR $\left(100 \mathrm{MHz}, \mathrm{CDCl}_{3}\right): \delta-138.27,{ }^{l} J_{\mathrm{Pt}-\mathrm{P}}=$ $2640 \mathrm{~Hz}$. FAB-MS: $m / z$ 1345.6(M $\left(\mathrm{M}^{+}\right)$. Calc. for $\mathrm{C}_{52} \mathrm{H}_{78} \mathrm{~S}_{2} \mathrm{O}_{4} \mathrm{P}_{4} \mathrm{Pt}_{2}$ : C, 46.42; H, 5.84. Found: C, 46.60; H, 5.90\%.

\section{Synthesis of $\mathrm{Pt}(\mathrm{II})$ poly-ynes}

trans- $\left[-\left({ }^{n} \mathrm{Bu}_{3} \mathrm{P}\right)_{2} \mathrm{Pt}-\mathrm{C} \equiv \mathrm{C}-\mathrm{R}-\mathrm{C} \equiv \mathrm{C}-\mathrm{I}_{n}, \quad(R=3,4\right.$-ethylenedioxythiophene-2,5-diyl) 1P. To a solution of trans- $\left[\mathrm{Pt}\left(\mathrm{PBu}_{3}^{n}\right)_{2} \mathrm{Cl}_{2}\right]$ $(0.1904 \mathrm{~g}, 0.28 \mathrm{mmol})$ and $\mathbf{1 b}(0.0540 \mathrm{~g}, 0.28 \mathrm{mmol})$ in ${ }^{i} \mathrm{Pr}_{2} \mathrm{NH} / \mathrm{CH}_{2} \mathrm{Cl}_{2}$ (25 mL,1:1,v/v) was added $\mathrm{CuI}(5 \mathrm{mg})$. The mixture was stirred at room temperature for $18 \mathrm{~h}$, after which all volatile compounds was removed under reduced pressure. The residue was dissolved in $\mathrm{CH}_{2} \mathrm{Cl}_{2}$ and passed through a short alumina column. Removal of the solvent under vacuum gave the title compound as a bright yellow solid $(0.17 \mathrm{~g}, 70 \%)$. Further purification was accomplished by precipitating the polymer solution from $\mathrm{CH}_{2} \mathrm{Cl}_{2}$ into methanol. $\operatorname{IR}\left(\mathrm{CH}_{2} \mathrm{Cl}_{2}\right): v \mathrm{~cm}^{-1} 2088 .{ }^{1} \mathrm{H}$ NMR (250 MHz, $\mathrm{CDCl}_{3}$ ): $\delta 4.18\left(\mathrm{~s}, 4 \mathrm{H}, \mathrm{H}_{\mathrm{EDOT}}\right), 2.17(\mathrm{~m}, 12 \mathrm{H}$,
$\left.\mathrm{H}_{\mathrm{P}-\mathrm{CH} 2}\right), 2.20\left(\mathrm{br}, 12 \mathrm{H}, \mathrm{H}_{\mathrm{CH} 2}\right), 1.52$ (sextet, $\left.12 \mathrm{H}, \mathrm{H}_{\mathrm{CH} 2}\right), 0.90(\mathrm{t}$, $\left.18 \mathrm{H}, \mathrm{H}_{\mathrm{CH} 3}\right) .{ }^{13} \mathrm{C}\left\{{ }^{1} \mathrm{H}\right\}$ NMR $\left(100 \mathrm{MHz}, \mathrm{CDCl}_{3}\right)$ : d 156.74, 139.19, 138.41, 128.76 (Arom.), 121.62 (C三C), 26.05-24.26, 13.83 (alkyl). ${ }^{31} \mathrm{P}\left\{{ }^{1} \mathrm{H}\right\} \mathrm{NMR}\left(101.3 \mathrm{MHz}, \mathrm{CDCl}_{3}\right): \delta-138.03,{ }^{l} J_{P_{t-P}}=2363 \mathrm{~Hz}$. Calc. for $\left(\mathrm{C}_{34} \mathrm{H}_{58} \mathrm{SO}_{2} \mathrm{P}_{2} \mathrm{Pt}\right)_{n}$ : C, 51.83; H, 7.42. Found: C, 51.94; H, $7.45 \%$. GPC (THF): $M_{n}=30,500(\mathrm{n}=66), \mathrm{M}_{\mathrm{w}}=52,008 \mathrm{gmol}^{-1}$ $\mathrm{gmol}^{-1}, \mathrm{PDI}=1.7$.

trans- $\left[\left(\mathrm{Bu}_{3} \mathrm{P}\right)_{2} \mathrm{Pt}-\mathrm{C} \equiv \mathrm{C}-\mathrm{R}-\mathrm{C} \equiv \mathrm{C}-\mathrm{I}_{n} \quad(\mathrm{R}=\mathbf{2 , 2}\right.$ '-bis-3,4-ethylenedioxythiophene-5,5'-diyl) 2P. Similar procedure to the synthesis of $\mathbf{1 P}$ was applied using $\mathbf{2 b}(0.155 \mathrm{~g}, 0.470 \mathrm{mmol})$, trans$\left[\left(\mathrm{PBu}_{3}\right)_{2} \mathrm{PtCl}_{2}\right](0.315 \mathrm{~g}, 0.47 \mathrm{mmol})$ in $\mathrm{THF} /{ }^{i} \mathrm{Pr}_{2} \mathrm{NH}(50 \mathrm{~mL}, 1: 1$ $\mathrm{v} / \mathrm{v})$ and $\mathrm{CuI}(5 \mathrm{mg})$ under $\mathrm{N}_{2}$. $2 \mathbf{P}$ was isolated in $(0.26 \mathrm{~g}, 70 \%$ yield). Further purification was accomplished by precipitating the polymer solution from $\mathrm{CH}_{2} \mathrm{Cl}_{2}$ into methanol. $\mathrm{IR}\left(\mathrm{CH}_{2} \mathrm{Cl}_{2}\right): v \mathrm{~cm}^{-1}$ $2085(-\mathrm{C} \equiv \mathrm{C}-) .{ }^{1} \mathrm{H}$ NMR $\left(250 \mathrm{MHz}, \mathrm{CDCl}_{3}\right): \delta 5.20 \mathrm{ppm}(\mathrm{s}, 8 \mathrm{H}$, $\mathrm{H}_{\text {EDOT }}$ ), $2.0 \mathrm{ppm}\left(\mathrm{t}, 12 \mathrm{H}, \mathrm{H}_{\mathrm{P}-\mathrm{CH} 2}\right), 1.50 \mathrm{ppm}\left(\mathrm{tt}, 12 \mathrm{H}, \mathrm{H}_{\mathrm{P}-\mathrm{CH} 2}\right), 1.30$ ppm (qt, 12H, $\left.\mathrm{H}_{\mathrm{P}-\mathrm{CH} 2}\right), 0.85 \mathrm{ppm}\left(\mathrm{t}, 18 \mathrm{H}, \mathrm{H}_{\mathrm{P}-\mathrm{CH} 3}\right) .{ }^{31} \mathrm{P}\left\{{ }^{1} \mathrm{H}\right\} \mathrm{NMR}$ $\left(101.3 \mathrm{MHz}, \mathrm{CDCl}_{3}\right): \delta-137.5$. Calc. for $\left(\mathrm{C}_{40} \mathrm{H}_{62} \mathrm{~S}_{2} \mathrm{O}_{4} \mathrm{P}_{2} \mathrm{Pt}\right)_{n}: \mathrm{C}$, 51.77; H, 6.73. Found: C, 51.83; H, 6.80\%. GPC (THF): $M_{n}=$ $29,556 \mathrm{gmol}^{-1}(n=44), \mathrm{Mw}=40,836 \mathrm{gmol}^{-1}, \mathrm{PDI}=1.4$.

\section{Acknowledgements}

We acknowledge Sultan Qaboos University (SQU) for the Research Grant No. IG/SCI/CHEM/09/02 and for research leave for MSK. We are grateful to the British Council for a PMI Grant (GS 216) that has supported MSK, MKA-S, HHS and PRR. PRR gratefully acknowledges support from the EPSRC through the award of a Senior Fellowship.

\section{Notes and references}

1 J. H. Burroughs, D. D. Bradley, A. R. Brown, R. N. Marks, K. Mckay and R. H. Friend et al., Nature, 1990, 347, 539; A. Kraft, A. C. Grimsdale and A. B. Holmes, Angew. Chem., Int. Ed., 1998, 37, 403; A. Montali, P. Smith and C. Weder, Synth. Met., 1998, 97, 123.

2 N. Tessler, G. J. Denton and R. H. Friend, Nature, 1996, 382, 695; H. Meier, Angew. Chem., Int. Ed. Engl., 1992, 31, 1399.

3 J. J. M. Halls, C. A. Walsh, N. C. Greenham, E. A. Marseglia, R. H. Friend and S. C. Moratti et al., Nature, 1995, 376, 498; A. Kohler, H. F. Wittmann, R. H. Friend, M. S. Khan and J. Lewis, Synth. Met., 1994, 67, 245; A. Kohler, H. F. Wittmann, R. H. Friend, M. S. Khan and J. Lewis, Synth. Met., 1996, 77, 147.

4 C. Caliendo, I. Fratoddi, M. V. Russo and C. L. Sterzo, J. Appl. Phys., 2003, 93, 10071; T. M. Swager, Acc. Chem. Res., 1998, 31, 201; D. T. McQuade, A. E. Pullen and T. M. Swager, Chem. Rev., 2000, 100, 2537.

5 D. K. Das-Gupta, in Introduction to Molecular Electronics, ed. M. C. Petty, M. R. Bryce and D. Bloor, Edward Arnold, London, 1995, pp. 47-71.

6 L. Feringa, W. F. Jager and B. de Lange, Tetrahedron, 1993, 49, 8267; G. H. W. Buning, in Org. Mater. Photonics, Ed. G. Zerbi, Elsevier, Amsterdam, 1993, pp.367-397.

7 K. Lösch, Macromol. Symp., 1995, 100, 65; J.-M. Lehn, Supramolecular Chemistry: Concepts and Perspectives, VCH, Weinheim, 1995, pp. 124 138P. J. Martin, in Introduction to Molecular Electronics, ed. M. C. Petty, M. R. Bryce and D. Bloor, Edward Arnold, London, 1995. pp. 112-141; J.-J. Kim and E.-H. Lee, Mol. Cryst. Liq. Cryst., 1993, 227, 71; Photochromism, Molecules and Systems, ed. H. Durr and H. BouasLaurent, Elsevier, Amsterdam, 1990; H. Durr, Angew. Chem., Int. Ed. Engl., 1989, 28, 413.

8 S. R. Marder, B. Kippelen, A. K.-Y. Jen and N. Peyghambarian, Nature, 1997, 388, 845; A. J. Heeger and J. Long Jr., Opt. Photonics News, 1996, 7(8), 24; H. S. Nalwa, in Nonlinear Optics of Organic Molecules and Polymers, ed. H. S. Nalwa and S. Miyata, CRC, New York, 1997, pp 611-787. 
9 D. Fichou, Handbook of Oligo- and Poly-thiophene, Willey-VCH: Weinheim, Germany and New York, 1999; A. Dodabalpur, L. Torsi and E. H. Katz, Science, 1995, 268, 270; Y. Kim, S. Cook, S. M. Tuladhar, S. A. Choulis, J. Nelson, J. R. Durrant, D. D. C. Bradley, M. Giles, I. Mc Culloch, C.-S. Ha and M. Ree, Nat. Mater., 2006, 5, 197; G. Li, V. Shrotriya, J. Huang, Y. Yao, T. Moriarty, K. Emery; and Y. Yang, Nat. Mater., 2005, 4, 864.

10 I. Manners, Synthetic Metal-Containing Polymers, Wiley-VCH, Weinheim, 2004U. S. Schubert, G. R. Newcome and I. Manners, MetalContaining and Supramolecular Polymers and Materials, 928, ACS, Washington, DC 2006; W-Y Wong and C-L Ho, Coord. Chem. Rev., 2006, 250, 2627; W-Y Wong and C-L Ho, in Frontiers in Transition Metal-Containing Polymers, ed. A. S. Abd-El-Aziz and I. Manners, Wiley-Hoboken, NJ 2007 (Chapter 6).

11 D. Beljonne, H. F. Wittmann, A. Kohler, S. Graham, M. Younus, J. Lewis, P. R. Raithby, M. S. Khan, R. H. Friend and J. L. Bredas, J. Chem. Phys., 1996, 105, 3868; A. Kohler, J. S. Wilson, R. H. Friend, M. K. Al-Suti, M. S. Khan, A. Gerhard and H. Bassler, J. Chem. Phys., 2002, 116, 9457; E. E. Silverman, T. Cardolaccia, X. M. Zhao, K. Y. Kim, K. Haskins-Glusac and K. S. Schanze, Coord. Chem. Rev., 2005, 249, 1491; K. Glusac, M. E. Kose, H. Jiang and K. S. Schanze, J. Phys. Chem. B, 2007, 111, 929; W. Y. Wong, Dalton Trans., 2007, 4495; T. Cardolaccia, A. M. Funston, M. E. Kose, J. M. Keller, J. R. Miller and K. S. Shanze, J. Phys. Chem. B, 2007, 111, 10871; L. Yang, J-K Feng, W-Y Wong and S-Y Poon, Polymer, 2007, 48, 6457; G. R. Whittel and I. Manners, Adv. Mater., 2007, 19, 3439; F. Guo, Y-G Kim, J. R. Reynolds and K. S. Shanze, Chem. Commun., 2006, 1887; N. J. Long and C. K. Williams, Angew. Chem., Int. Ed., 2003, 42, 2586; V. W.-W. Yam, Acc. Chem. Res., 2002, 35, 555; M. P. Cifuentes and M. G. Humphrey, J. Organomet. Chem., 2004, 689, 3968; A. Köhler and D. Beljonne, Adv. Funct. Mater., 2004, 14, 11; J. S. Wilson, N. Chawdhury, M. R. A. AlMandhary, M. Younus, M. S. Khan, P. R. Raithby, A. Kohler and R. H. Friend, J. Am. Chem. Soc., 2001, 123, 9412.

12 J. Lewis, N. J. Long, P. R. Raithby, G. P. Shield, W.-Y. Wong and M. Younus, J. Chem. Soc., Dalton Trans., 1997, 4283; N. Chawdhury, A. Kohler, R. H. Friend, W.-Y. Wong, M. Younus, P. R. Raithby, J. Lewis, T. C. Corcoran, M. R. A. Al-Mandhary and M. S. Khan, J. Chem. Phys., 1999, 110, 4963; L. S. Devi, M. K. Al-Suti, N. Zhang, S. J. Teat, L. Male, H. A. Sparks, P. R. Raithby, M. S. Khan and A. Kohler, Macromolecules, 2009, 42, 1131.

13 J. Roncali, P. Blanchrad and P. Frere, J. Mater. Chem., 2005, 15, 1589.

14 S. Akoudad and J. Roncali, Synth. Met., 1999, 101, 149; P. Buvat and P. Hourquebie, Synth. Met., 1999, 101, 17; L. B. Groenendaal, F. Jonas, D. Frietag, H. Pielartzik and J. R. Reynolds, Adv. Mater., 2000, 12, 481; M. Turbiez, P. Frere, P. Blanchard and J. Roncali, Tetrahedron Lett., 2000, 41, 5521; H. J. Abonen, J. Lukkari and J. Kankare, Macromolecules, 2000, 33, 6787; J. J. Apperloo, L. B. Groenendaal, H. Verheyen, M. Jayakannan, R. A. J. Janssen, A. Dhikissi, D. Beljonne, R. Lazzaroni and J-L Bredas, Chem. Eur. J., 2002, 8, 2384; P. Leriche, M. Turbiez, V. Monroche, P. Frere, P. Blanchard, P. J. Skabara and J. Roncali, Tetrahedron Lett., 2003, 44, 649; H. Meng, D. F. Perepichka, M. Bendikov, F. Wudl, G. Z. Pan, W. Yu, W. Dong and S. Brown, J. Am. Chem. Soc., 2003, 125, 15151; L. B. Groenendaal, G. Zotti, P.H Aubert, S. M. Waybright and J. R. Reynolds, Adv. Mater., 2003, 15, 855; H. Meng, D. F. Perepichka and F. Wudl, Angew. Chem., Int. Ed., 2003, 42, 658; H. Spencer, R. Berridge, D. J. Crouch, S. P. Wright, M. Giles, I. McCulloch, S. Coles, M. B. Hursthouse and P. J. Skabara, J. Mater. Chem., 2003, 13, 2075; M. Turbiez, P. Frere and J. Roncali, J. Org. Chem., 2003, 68, 5357; J. Cao, J. W. Kampf and M. D. Curtis, Chem. Mater., 2003, 15, 404; H. Meng, D. Tucker, S. Chaffins, Y. Chen, R. Helgeson, B. Dunn and F. Wudl, Adv. Mater., 2003, 15, 146; J-Y Kim, M-H Kwon, Y-K Min, S. Kwon and D-W Ihm, Adv. Mater., 2007, 19, 3501; J. G. Bokria, A. Kumar, V. Seshadri, A. Tran and G. A. Sotzing, Adv. Mater., 2008, 20, 1175.

15 W.-Y. Wong, X. Wang, H-L Zhang, K-Y Cheung, M-K Fung, A. B. Djuristic and W-K Chan, J. Organomet. Chem., 2008, 693, 3603; J. Mei, K. Ogawa, Y-G Kim, N. C. Heston, D. J. Arenas, Z. Nasrollahi, T. D. McCarley, D. B. Tanner, J. R. Reynolds and K. S. Shanze, ACS Appl. Mater. Interfaces, 2009, 1, 150.

16 K. Mullen and G. Wegner, Electronic Materials: The Oligomer Approach, Wiley-VCH, New York, 1998; J. Roncali, Chem. Rev., 1997, 97,
173; I. Jestin, P. Frere, P. Blanchard and J. Roncali, Angew. Chem., Int. Ed., 1998, 37, 942.

17 M. S. Khan, M. R. A. Al-Mandhary, M. K. Al-Suti, P. R. Raithby, B. Ahrens, L. Male, R. H. Friend, A. Köhler and J. S. Wilson, Dalton Trans., 2003, 65.

18 M. S. Khan, M. R. A. Al-Mandhary, M. K. Al-Suti, T. C. Corcoran, J. P. Attfield, N. Feeder, W. I. F. David, K. Shankland, R. H. Friend, A. Köhler, E. A. Marseglia, E. Tedesco, C. C. Tang, P. R. Raithby, J. C. Collings, K. P. Roscoe, A. S. Batsanov, L. M. Stimson and T. B. Marder, New J. Chem., 2003, 27, 140; J. Cornil, D. A. dos Santos, X. Crispin, R. Silbey and J. L. Bredas, J. Am. Chem. Soc., 1998, 120, 1289; U. H. F. Bunz, V. Enkelmann, L. Koppenbug, D. Jones, K. D. Shimizu, J. B. Claridge, H.-C. zur Loye and G. Leisure, Chem. Mater., 1999, 11, 1416.

19 S. Thorand and N. Krause, J. Org. Chem., 1998, 63, 8551; M. Moroni, J. Le Moigne, T. A. Pham and J.-Y. Bigot, Macromolecules, 1997, 30, 1964; C. Weder and M. S. Wrighton, Macromolecules, 1996, 29, 5157.

20 M. S. Khan, M. R. A. Al-Mandhary, M. K. Al-Suti, A. K. Hisham, P. R. Raithby, B. Ahrens, M. F. Mahon, L. Male, E. A. Marseglia, E. Tedesco, R. H. Friend, A. Köhler, N. Feeder and S. J. Teat, J. Chem. Soc., Dalton Trans., 2002, 1358; M. S. Khan, M. R. A. Al-Mandhary, M. K. Al-Suti, N. Feeder, S. Nahar, A. Köhler, R. H. Friend, P. J. Wilson and P. R. Raithby, J. Chem. Soc., Dalton Trans., 2002, 2441; M. S. Khan, M. R. A. Al-Mandhary, M. K. Al-Suti, P. R. Raithby, B. Ahrens, M. Mahon, L. Male, C. E. Boothby and A. Köhler, Dalton Trans., 2003, 74

21 J. B. Lambert, H. F. Shurvell, D. Lightnen, R. G. Cooks, Introduction to Organic Spectroscopy, McMillan, New York, 1987, pp. 204.

22 J. Manna, K. D. John and M. D. Hopkins, Adv. Organomet. Chem., 1995, 38, 79.

23 M. S. Khan, B. Ahrens, L. Male and P. R. Raithby, Acta Crystallogr., Sect. E., 2002, 58, O1220; M. S. Kahn, B. Ahrens, M. F. Mahon, L. Male and P. R. Raithby, Acta Crystallogr., Sect. E., 2002, 58, O1202; M. S. Khan, L. Male, P. R. Raithby, S. J. Teat and A. D. Bond, Acta Crystallogr., Sect. E., 2003, 59, O1342; M. S. Khan, B. Ahrens, L. Male and P. R. Raithby, Acta Crystallogr., Sect. E, 2004, 60, O915.

24 D. Cremer and J. A. Pople, J. Am. Chem. Soc., 1975, 97, 1354

25 J. Storsberg, D. Schollmeyer and H. Ritter, Chem. Lett., 2003, 32, 140; A. Kumar, D. M. Welsh, M. C. Morvant, F. Piroux, K. A. Abboud and J. R. Reynolds, Chem. Mater., 1998, 10, 896.

26 J. Lewis, N. J. Long, P. R. Raithby, G. P. Shields, W.-Y. Wong and M. Younus, J. Chem. Soc., Dalton Trans., 1997, 4383; M. S. Khan, M. K. Al-Suti, M. F. Mahon, L. Male and P. R. Raithby, Acta Crystallogr., Sect. E, 2003, 59, m833.

27 C. B. Nielsen, A. Angerhofer, K. A. Abboud and J. R. Reynolds, J. Am. Chem. Soc., 2008, 130, 9734.

28 J.-M. Raimundo, P. Blanchard, P. Frère, N. Mercier, I. Ledoux-Rak, R. Hierle and J. Roncali, Tetrahedron Lett., 2001, 42, 1507.

29 J. S. Wilson, A. Köhler, R. H. Friend, M. K. Al-Suti, M. R. A. AlMandhary, M. S. Khan and P. R. Raithby, J. Chem. Phys., 2000, 113, 7627.

30 N. Chawdhury, A. Köhler, R. H. Friend, M. Younus, N. J. Long, P. R. Raithby and J. Lewis, Macromolecules, 1998, 31, 722.

31 F. Wittmann, R. H. Friend, M. S. Khan and J. Lewis, J. Chem. Phys., 1994, 101, 2693.

32 N. Chaudhury, Ph. D. Thesis, University of Cambridge, 1998.

33 W. L. F. Armarego, D. D. Perrin, Purification of Laboratory Chemicals, 4th edn, Butterworth-Heinemann, Guildford, UK, 1996.

34 K. Siegmann, P. S. Pregosin and L. M. Venanzi, Organometallics, 1989, 8, 2659.

35 G. B. Kaufman and L. A. Teter, Inorg. Synth., 1963, 7, 248.

36 G. A. Sotzing, J. R. Reynolds and P. J. Steel, Adv. Mater., 1997, 9, 795.

37 G. A. Sotzing, J. R. Reynolds and P. J. Steel, Chem. Mater., 1996, 8, 882.

38 For GPC procedural details see: S. Takahashi, M. Kariya, T. Yatake, K. Sonogashira and C. U. Pittman, Jr., ed., Organometallic Polymers, Academic Press, New York, 1978.

39 A. Altomare, M. C. Burla, G. Camalli, G. Cascarano, C. Giacovazzo, A. Gualiardi and A. Polidori, J. Appl. Cryst., 1994, 27, 435.

40 G. M. Sheldrick, Acta Crystallogr., Sect. A, 2008, 64, 112. 